\title{
Aleksandra Juszczyk
}

Szkoła Doktorska Nauk Humanistycznych i Społecznych, Uniwersytet Gdański

ORCID: 0000-0002-5148-1807

\section{Wczesny okres twórczości Hanny Żuławskiej. Warszawa-Paryż-Gdynia}

\author{
https://doi.org/10.26881/porta.2021.20.07
}

Słowa kluczowe: Hanna Żuławska, koloryzm, dwudziestolecie międzywojenne, Akademia Sztuk Pięknych w Warszawie, Filia Paryska Akademii Sztuk Pięknych w Krakowie, Instytut Propagandy Sztuki (IPS), Związek Zawodowy Polskich Artystów Plastyków (ZZPAP)

Keywords: Hanna Żuławska, colorism, interwar period, Warsaw School of Fine Arts, Paris Branch of the Academy of Fine Arts in Krakow, Art Propaganda Institute, Trade Union of Polish Artists and Designers

Hanna Żuławska (1908-1988) była jedną z najwybitniejszych artystek związanych z Trójmiastem. Znana jest przede wszystkim ze swej dojrzałej twórczości, przypadającej na lata pięćdziesiąte i sześćdziesiąte XX w. Pokazała wówczas prawdziwą indywidualność jako malarka, pedagog, kierowniczka „Grupy Ceramików Kadyny”, ale przede wszystkim jako wybitna autorka wielkoformatowych mozaik, malowideł architektonicznych i sgraffit na odbudowywanych fasadach staromiejskich kamienic w Gdańsku i nowo wznoszonych gmachach w Warszawie oraz jako twórczyni „odwilżowych” realizacji ceramicznych.

Mało, o ile w ogóle, znana jest twórczość Żuławskiej z okresu dwudziestolecia międzywojennego. Historia jej edukacji, drogi artystycznej i inspiracji twórczych wymaga rekonstrukcji i przynajmniej próby charakterystyki. Poszukiwania odpowiedzi na pytanie, czy droga ta była typowa dla artystów dwudziestolecia międzywojennego? Co skłoniło artystkę, rodowitą warszawiankę, do wyjazdu do Paryża, a potem do Gdyni?

Dla badacza zajmowanie się twórczością Żuławskiej z czasów dwudziestolecia międzywojennego jest trudne i problematyczne. Po pierwsze, właściwie nie zachowały się jej prace malarskie ani projekty polichromii z tego okresu. Po drugie, jej związek życiowy i artystyczny z Jackiem Żuławskim był wtedy tak zażyły, mąż miał na nią - jak można przypuszczać - tak duży wpływ, że artystka nie miała szansy zaistnieć wówczas w świecie sztuki jako samodzielna indywidualność, nastąpiło to dopiero po wojnie. Żuławska nie pisała żadnych pamiętników (a przynajmniej nic o tym nie wiadomo), nie zachowały się też żadne jej listy z okresu międzywojennego. Właściwie jedyna jej osobista opowieść o tym czasie pochodzi z tomu 
poświęconego Jackowi Żuławskiemu, wydanego po jego śmierci. Do książki tej napisała rozdział o ich życiu przed wojną zatytułowany Lata młodzieńcze'. Zachowało się zaledwie kilka namalowanych przez nią, dość mało oryginalnych obrazów, pejzaży i martwych natur, a także kilka rycin, np. Pejzaż(il. 1), Narciarze (il. 2), Martwa natura, oraz rysunków (il. 3). Śledzenia przedwojennych losów Żuławskiej nie ułatwia fakt, że w czasach Polski Ludowej rzadko wspominano o przedwojennych działaniach artystycznych i twórczości późniejszej wykładowczyni Państwowej Wyższej Szkoły Plastycznej.

Hanna, a właściwie Anna ${ }^{2}$ Klementyna Żuławska urodziła się 23 listopada $1908 \mathrm{r}^{3}{ }^{3} \mathrm{w}$ Warszawie. Jej ojcem był Józef Jasiński, a matką Wanda Jasińska $z$ domu Pusch. Jej rodzina miała tradycje artystyczne i inteligenckie. Józef Jasiński ${ }^{4}$ był rzeźbiarzem, absolwentem Szkoły Sztuk Pięknych w Krakowie (studia pod kierunkiem Alfreda Dauna), a także Académie Julian w Paryżu. Działał zawodowo w Rzymie i Zakopanem (1919-1922), w Warszawie kierował w latach 1924-1939 pracownią kamieniarsko-odlewniczą w Miejskiej Szkole Sztuk Zdobniczych i Malarstwa, był twórcą pomników, portretów rzeźbiarskich i rzeźby architektonicznej. Najpopularniejszą była zniszczona w czasie drugiej wojny światowej Apoteoza Muzyki (1901), zdobiąca gmach Filharmonii Narodowej w Warszawie 5 . Kolejnym artystą w rodzinie był stryj Hanny, Zdzisław Piotr Jasiński' ${ }^{6}$, popularny w Warszawie malarz sztalugowy zafascynowany impresjonizmem, członek stowarzyszenia Pro Arte, twórca obrazów rodzajowych, krajobrazów, portretów, martwych natur, obrazów religijnych. Był także autorem polichromii (np. w kościele św. Krzyża w Kozienicach w 1887 r., w Pałacyku Myśliwskim w Białowieży w 1894 r.), plafonów w pałacach w Petersburgu, Carskim Siole i w Moskwie (1896-1897) i we foyer Filharmonii Warszawskiej (1901). Otrzymał brązowy medal na Wystawie Światowej w Paryżu w 1900 r. za Portret A. Małeckiego. Najprawdopodobniej matka Żuławskiej miała także zainteresowania artystyczne,

1 Hanna Żuławska, Lata młodzieńcze [w:] Jacek Żuławski, red. Hanna Żuławska, Gdańsk 1987, s. 25-36.

2 Imię Anna było miała wpisane w dowodzie osobistym Żuławskiej (obecnie w posiadaniu Ewy Żuławskiej-Bogackiej). Zapewne artystka posługiwała się nim jeszcze w latach trzydziestych XX w. (prasa także używała tego imienia), jednak z czasem zaczęła używać tylko imienia Hanna i posługiwała się nim zarówno prywatnie, jak i oficjalnie.

3 W powszechnym obiegu funkcjonuje wciąż - jako data urodzin artystki - także rok 1909, zapewne dlatego, że sama Żuławska, nawet w pisanych odręcznie życiorysach (teczka Hanny Żuławskiej w ISPAN) lub akcie ślubu (dwa odpisy w posiadaniu Ewy Żuławskiej-Bogackiej) podawała właśnie taką datę. W dowodzie osobistym z 1965 r. zapisano rok 1908. Podobne informacje zob. Ignacy Witz, Plastycy Wybrzeża, Gdańsk 1969, s. 243; Słownik artystów plastyków, Warszawa 1972, s. 684.

4 Jasiński Józef [w:] Słownik artystów polskich i obcych w Polsce działajacych. Malarze, rzeźbiarze, graficy, t. 3, red. Jolanta Maurin-Białostocka, Janusz Derwojed, Wrocław 1979, s. 260-261.

5 Ibidem.

$6 \quad$ Aneta Pawłowska, Pro Arte. Monografia grupy warszawskich artystów 1922-1932, Warszawa 2006, s. 110-111. Jasiński Zdzisław Piotr [w:] Polski słownik biograficzny, t. 11/1, z. 48, Warszawa 1964, s. 57-58.
Wczesny okres twórczości Hanny Żuławskiej... 


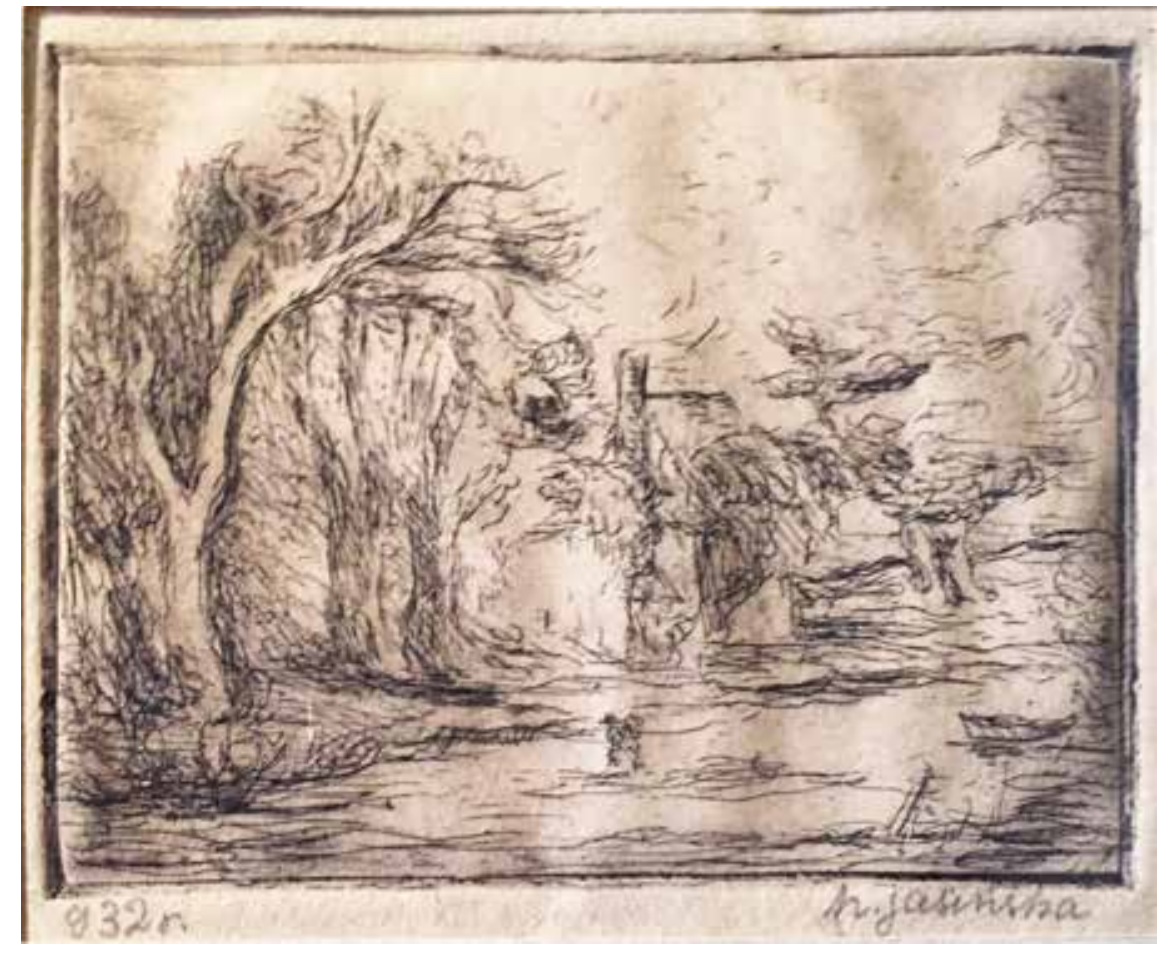

Il. 1. Hanna Żuławska, Pejzȧ̇, 1932, akwaforta, zbiory prywatne. fot. Aleksandra Juszczyk

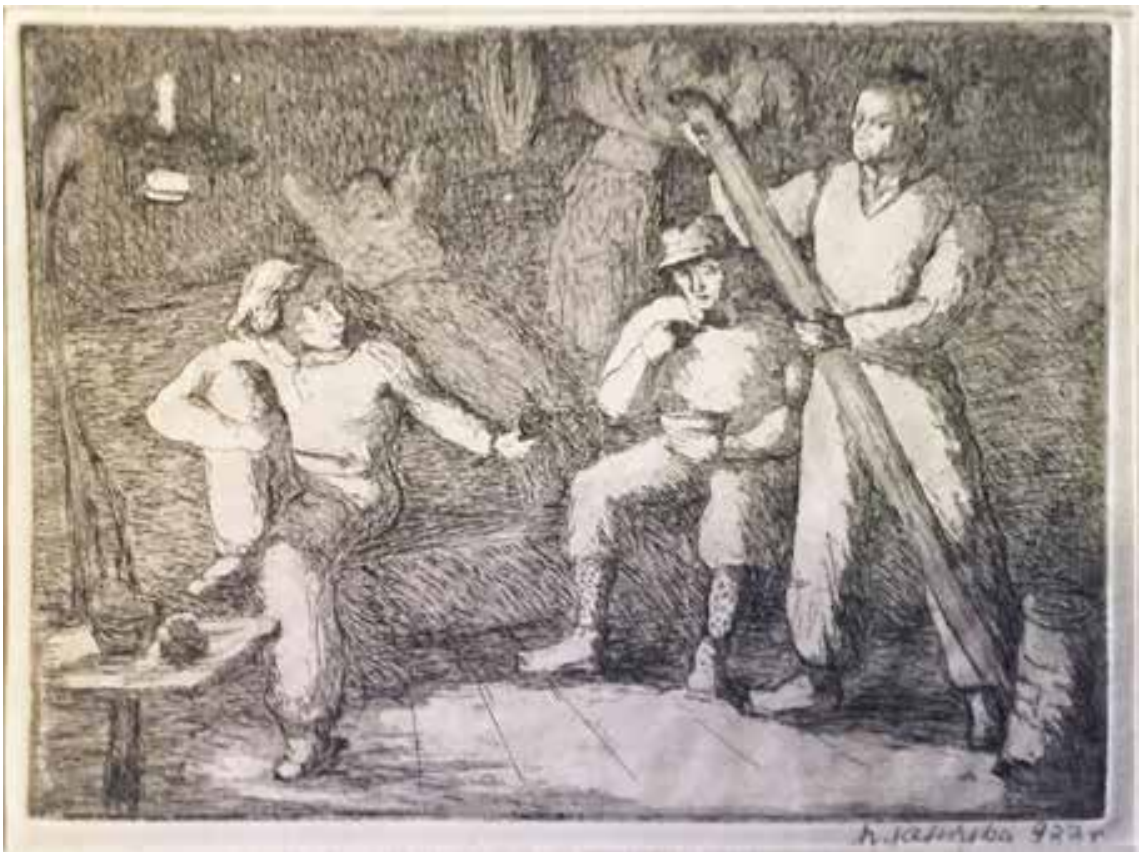

Il. 2. Hanna Żuławska, Narciarze, 1933, akwaforta, akwatinta, zbiory prywatne, fot. Aleksandra Juszczyk 
prowadziła bowiem czytelnię sztuki przy ul. Francuskiej w Warszawie. Wybór drogi życiowej Żuławskiej wydaje się zatem logiczny i nieprzypadkowy.

Przyszła artystka ukończyła gimnazjum humanistyczne przy ul. Konopnickiej w Warszawie (1928) i rozpoczęła w 1929 r. studia w warszawskiej Szkole Sztuk Pięknych ${ }^{7}$. Co prawda, liczba kobiet podejmujących w Polsce studia wyższe wzrosła po odzyskaniu niepodległości i reformie szkolnictwa przeprowadzonej na początku lat dwudziestych (w 1933 r. było ich na wszystkich wydziałach sztuk pięknych 255), jednak wciąż przeważali mężczyźni. Jednocześnie w nowym państwie, w którym kobiety uzyskały pełnię praw obywatelskich, pozycja kobiet uległa zmianie i kobieca aktywność artystyczna przestała wzbudzać kontrowersje, co nie znaczy, że przez niektórych mężczyzn nie była traktowana krytycznie czy wręcz z patriarchalnym pobłażaniem ${ }^{8}$.

Wydaje się, że Hanna wybrała studia pod wpływem tradycji rodzinnych, ale kontynuowała je za sprawą spotkania z przyszłym mężem,

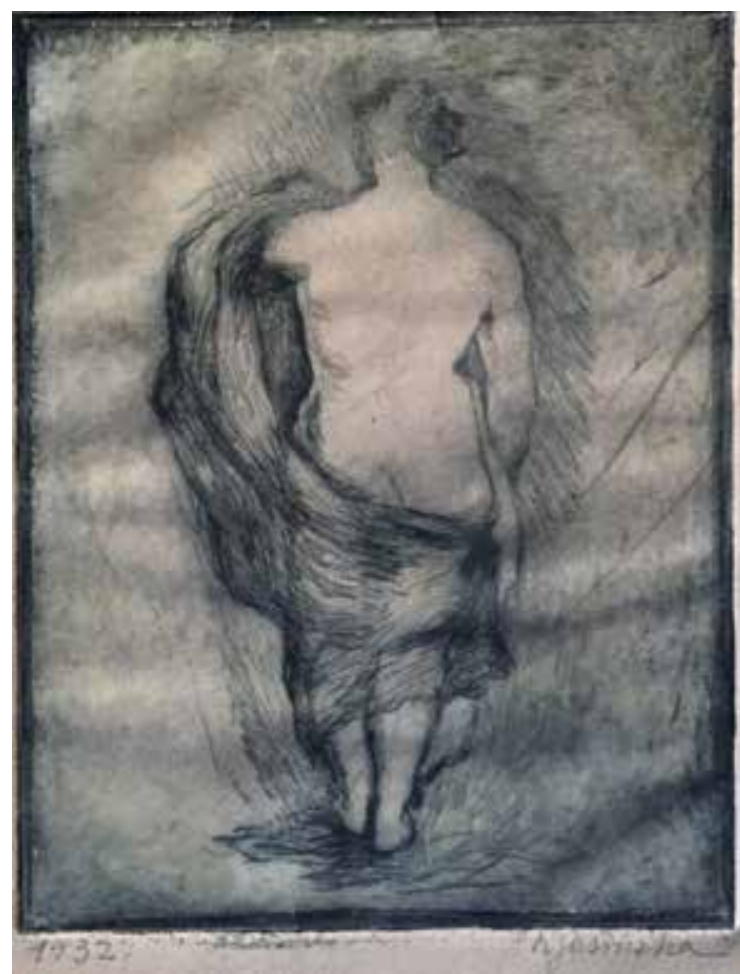

Il. 3. Hanna Żuławska, $A k t$, 1932, rysunek, zbiory prywatne, fot. Aleksandra Juszczyk które utwierdziło ją w słuszności tego wyboru. Żuławski przeniósł się z uczelni krakowskiej do Warszawy, by podążyć - jak wielu innych studentów tej uczelni (żeby wymienić tylko tak ważne w przyszłości w życiu artystki osoby, jak Juliusz Studnicki, Krystyna Łada czy Jan Wodyński) - za swym mistrzem Felicjanem Szczęsnym Kowarskim, który przeniesiony służbowo, od 1929 r. miał przewodzić stołecznej pracowni malarstwa monumentalnego'.

W pierwszych miesiącach nauki w SSP sportsmenkę Hannę bardziej niż studiowanie malarstwa fascynowały zajęcia w AZS-ie: „pływanie i wiosłowanie”. Wspominała: „byłam wtedy na I roku ASP, gdzie znalazłam się jako córka rzeźbiarza Józefa Jasińskiego - ale nie mogę powiedzieć, żeby studia artystyczne w tym czasie odgrywały poważniejszą rolę w moim życiu [...]

7 Teczka osobowa Hanny Żuławskiej, Archiwum ASP w Gdańsku.

8 Joanna Sosnowska, Artystki w dwudziestoleciu [w:] Artystki polskie, red. Agata Jakubowska, Warszawa 2011, s. 66-68.

9 Żuławska, Lata młodzieńcze..., s. 27. 
Aleksandra dopiero jak przyjechali «krakowiacy», zaczęłam pracować na serio. Jakby Juszczyk powiał świeży wiatr z przyjazdem Kowarskiego [inna sprawa, że pojawił się wtedy Jacek Żuławski - przyszły mąż artystki - przyp. autorki]. Kowarski przywiózł ze sobą całą wielką problematykę malarstwa, zarówno klasycyzmu, jak i romantyzmu. Prowadził pracownię opartą na studium z natury, przywiązując wielką wagę do umiejętności rysowania i budowania obrazu kolorem i walorem. Podczas długich korekt tłumaczył prawa nieskończonego kontrastu, czasem na naszych płótnach, ale często przynosił albumy z reprodukcjami Delacroix, Chardina, Daumiera, a także wielkich Włochów. Bliskie mu było malarstwo monumentalne, działające wielką formą, wyrażające ogólnoludzkie treści. [...] zadziwiał nas swoją erudycją i czarował rzetelnymi korektami” ${ }^{10}$. Warto zaznaczyć, że Szczęsny-Kowarski stał się pierwszym (lub drugim, jeśli uznamy za takiego ojca) mentorem artystki. Jak się wydaje, miał również wpływ na jej dojrzałą drogę artystyczną. Ten malarz kolorysta, twórca malarstwa monumentalnego, członek Warszawskiej Grupy Artystów Plastyków „Pryzmat” (1933-1939), był już wtedy autorem takich realizacji, jak polichromie kamienic Gizów i Dzianotów na Rynku Starego Miasta w Warszawie (1928), temperowe przedstawienie Wieczerzy Pańskiej w jednej z kaplic klasztoru oo. paulinów na Jasnej Górze w Częstochowie (koniec lat dwudziestych XX w., niezachowane) czy dekoracja stropu Sali Pod Ptakami na Wawelu (1929), złożona z siedemnastu malowideł $w$ technice olejnej ${ }^{11}$.

Już w latach późniejszych Kowarski zwykł zapraszać do pracy przy projektach monumentalnych realizacji najzdolniejszych studentów, także tych byłych. Było tak np. przy projektowaniu polichromii wnętrza kościoła Najświętszej Marii Panny w Chełmnie ${ }^{12}$ (projekt nie został zrealizowany). W teczce Żuławskiej w Instytucie Sztuki PAN w Warszawie jest dostępna ankieta z życiorysem artystki, w którym pisze ona o swoim udziale w konkursie na tę realizację, a nawet wspomina o otrzymaniu wyróżnienia (w pracach uczestniczył też jej późniejszy mąż Jacek) ${ }^{13}$. Najprawdopodobniej brała udział w tym projekcie jako studentka, pomagając $\mathrm{w}$ pracach, ale jej nazwisko nie pojawiło się $\mathrm{w}$ doniesieniach prasowych o konkursie. W ankiecie Żuławskiej znajduje się też informacja, iż brała ona udział w konkursie na polichromię centralnej części ściany hali odjazdowej Dworca Głównego w Warszawie (1939). W konkursie tym I nagrodę zdobył jej wykładowca - Kowarski - za projekt monumentalnej mozaiki architektonicznej z przedstawieniami kontynentów. Zapewne i tu Żuławska pomagała w pracach jako wyróżniona w ten sposób, zdolna, była już studentka, ale i w tym przypadku jej nazwisko nie pojawiło się w informacjach o konkursie ${ }^{14}$. Również i ten projekt nie doczekał się realizacji ze względu na wybuch drugiej wojny światowej.

$10 \quad$ Ibidem, s. 27.

11 Kowarski Felicjan Szczęsny [w]: Słownik artystów..., s. 207-212.

12 Projekt otrzymał I nagrodę w konkursie IPS, zob. ibidem, s. 209.

13 Żuławska, Jacek Żuławski..., s. 28.

14 Teczka osobowa Hanny Żuławskiej, Dział Dokumentacji Sztuki Współczesnej, Instytut Sztuki PAN Warszawa. 
Można przypuszczać, że i Żuławską już wtedy pociągało praktykowane przez Kowarskiego łączenie malarstwa i architektury; oboje z Jackiem zapisali się także do pracowni malarstwa monumentalnego prowadzonej przez Leona Pękalskiego, współpracownika Kowarskiego, również członka grupy „Pryzmat”. Artystka nauczyła się tam pracy w technice mozaikowej, al fresco, al secco i sgraffita - technikach, na które otrzymała w powojennych czasach wiele zleceń i w których osiągnęła największe uznanie. Bardzo możliwe jednak, że zainteresowanie Hanny malarstwem ściennym było znacznie wcześniejsze, wszak jej stryj Zdzisław Jasiński zyskał na tym polu pewną renomę i dziewczyna od dziecka mogła obserwować efekty jego pracy.

Równocześnie Hanna poznawała tajniki malarstwa sztalugowego i tworzyła w technice olejnej, wystawiając obrazy w galeriach. W dniu 18 listopada 1933 r. wręczono jej jedną z równorzędnych drugich nagród dla młodych artystów uczestniczących w obozach letnich im. Karola Stryjeńskiego. Obozy te, w których udział brało wielu młodych adeptów wyższych szkół plastycznych, były organizowane przez Państwowy Urząd Wychowania Fizycznego i Przysposobienia Obronnego oraz Instytut Propagandy Sztuki. Miały na celu krzewienie kultury fizycznej wśród młodzieży artystycznej i były jednocześnie plenerami sztuki: uprawiano na nich sport, chodzono na piesze wycieczki, a także zajmowano się rzeźbą i malarstwem. Każdy z uczestników takich obozów musiał podarować jedną z powstałych tam prac Muzeum Sportowemu P.U.WF. i PW ${ }^{15}$. Najlepsze dzieła nagradzano, a projekty młodych artystów można było oglądać finalnie na wystawie zorganizowanej w kawiarni Instytutu Propagandy Sztuki (Cafe IPS $)^{16}$. Hanna wystawiała w IPS aż do wybuchu drugiej wojny światowej.

Artystka poznała kuzyna swojego przyszłego męża - Marka, również malarza i taternika, uczestnika obozów im. Karola Stryjeńskiego. Razem z nim oraz graficzką Marią Obrębską narzeczeni uczestniczyli w styczniu 1934 r. w kolejnej wystawie (ale nie wystawiali na otwartym 5 stycznia IV Salonie Jesiennym) w Cafe IPS ${ }^{17}$. Hanna zaprezentowała na niej kilkanaście temperowych prac, będących efektem wakacyjnych studiów na wolnym powietrzu. Ekspozycja jako całość została oceniona pozytywnie, czemu dał wyraz recenzent czasopisma „Pion”: „szereg bardzo esencjonalnych studiów z natury - gdzie głównym czynnikiem kompozycji jest barwa - nie jako lokalny kolor przedmiotów we wzrokowym polu widzenia, lecz jako samoistny i samodzielny środek artystyczny

15 Instytut Sztuki PAN, Zbiory Specjalne, Regulamin Obozów im Karola Stryjeńskiego.

16 Laureatami II Nagrody, przyznanej 8 listopada 1933 r., byli także stryjeczni bracia - Jacek i Marek Żuławscy, zob. Polskie życie artystyczne w latach 1915-1939, t. 2, red. Aleksander Wojciechowski, Wrocław-Warszawa-Kraków-Gdańsk 1974; „Nike” 1937, R. 1, s. 237; „Głos Plastyków” 1933, R. 3, nr 7-8, s. 98; „Sztuki Piękne” 1933, R. 9, s. 413-414. Zob. też ISPAN, Zbiory Specjalne, Protokół obrad w IPS dotyczących obozów letnich P.U.W.F. z dn. 18 XI 1933 r.; Joanna Sosnowska, Przedmowa [w:] Materialy dziejów Instytutu Propagandy Sztuki (1930-1939), red. Joanna Sosnowska, Warszawa 1990, s. 8.

17 „Głos Plastyków” 1933, R. 3, nr 5-6, s. 98; „Pion” 1934, nr 5, s. 87-88; „Sztuki Piękne” 1934, R. 10, s. 17; K.W., Wystawa temper H. Jasińskiej i J. i M. Żuławskich, „Pion” 1934, nr 5, s. 10. 
w budowie malowidła. Tym się właśnie różni ortodoksyjny impresjonizm cza, posiada nader licznych, a entuzjastycznych przy tym i wysoce uzdolnionych wyznawców i wielbicieli”18.

Faktycznie w czasie studiów Hanna i Jacek należeli do zwolenników malarstwa postimpresjonistycznego, obracali się w kręgach związanych z koloryzmem, utrzymywali przyjacielskie kontakty z członkami grupy „Pryzmat” - Janem Wodyńskim i Juliuszem Studnickim, późniejszym dziekanem wydziału malarstwa (który w 1945 r. będzie jednym z założycieli pierwszej wyższej uczelni plastycznej na Wybrzeżu). Żuławscy jednak nie wstąpili w szeregi tego czynnie wystawiającego od 1933 r. ugrupowania. Hanna zachwycona twórczością członów „Komitetu Paryskiego”19, którzy powrócili właśnie z Francji i znaleźli się w centrum zainteresowania, nie była tu wyjątkiem. Oboje z Jackiem wzięli udział w drugiej z warszawskich wystaw kapistów w Instytucie Propagandy Sztuki w 1934 r. (otwartej 23 marca). „Ten atak koloru był dla nas niemalże rewolucją w myśleniu o możliwościach w malarstwie” - pisała. - „Toteż wrzało w Akademii, nie kończyły się dyskusje na temat «jak malować», przeciw temu «co malować»" 20 .

W wyniku fascynacji koloryzmem i twórczością Pierre’a Bonnarda, a niebawem także Paula Cèzanne’a, Hanna i jej narzeczony ${ }^{21}$ podjęli zakończone sukcesem - dzięki dotacji krakowskiej ASP - starania o uzyskanie stypendium na wyjazd do Paryża. Stypendia do Paryża były od dawna przedmiotem politycznego dyskursu i były krytykowane przez nacjonalistów niechętnych awangardzie, zwłaszcza sympatyków Narodowej Demokracji, jako „dokument bezprzykładnego utracjuszostwa naszego narodu", jak pisał publicysta Adolf Nowaczyński ${ }^{22}$. Nieco inne zdanie na ten temat miał rektor krakowskiej ASP, Fryderyk Pautsch, który jednak też żywił obawy przed „obcym”, „nowym”: „Oddział paryski Akademii został stworzony w celu utrzymania wpływu i kierownictwa studiami młodzieży artystycznej wyjeżdżającej do Paryża dla uzupełnienia swego wykształcenia. Paryż ma pod tym względem doniosłe znaczenie $\mathrm{z}$ powodu nagromadzenia bogatych zbiorów sztuki, młodzież polska bowiem nie posiada w kraju potrzebnych wzorów i dlatego wyjazd z kraju jest jej niezbędny. Oddział w Paryżu pozostający pod kierownictwem delegowanego profesora Akademii, może należycie pokierować studiami młodzieży polskiej i ustrzec ją od wpływów niejednokrotnie niepożądanych

18 Ibidem.

19 W 1931 r. w Polskim Klubie Artystycznym hotelu „Polonia” otwarto pierwszą wystawę kapistów, zaś w 1934 r. - drugą, większą, w Instytucie Propagandy Sztuki.

20 Żuławska, Jacek Żuławski..., s. 28, 30.

21 Jasińska i Żuławski jechali do Paryża w tajemnicy, udając, że jadą osobno. Wydaje się, że w tę intrygę został wprowadzony także stryjeczny brat Jacka - Marek Żuławski, który też uzyskał stypendium, zob. Żuławska, Jacek Żuławski..., s. 32; Wojciech Zmorzyński, Jacek [w:] Marek i Jacek Żuławscy [katalog wystawy], Gdańsk 2002, s. 26.

22 Zob. Anna Wierzbicka, We Francji i w Polsce 1900-1939, Warszawa 2009, s. 54. 
pod względem artystycznym. Studiują tam absolwenci i stypendyści tak tutejszej, jak i innych uczelni artystycznych"23. Być może w decyzji o podróży do Francji chodziło zresztą po trosze o rodzinną tradycję - podróż artystyczną do Paryża odbył także stryj Hanny, i o to, że takie wyjazdy do stolicy Francji były w tym czasie wśród młodych malarzy wciąż bardzo en vogue. Studia w paryskim oddziale mieszczącym się przy Rue d'Alésia 210 były też niezwykle prestiżowe: mogli tam studiować absolwenci ASP krakowskiej i warszawskiej, a także Wydziału Sztuk Pięknych w Wilnie. Stypendia na jeden kurs otrzymywało od dwóch do sześciu osób, od 1925 r. do wybuchu drugiej wojny światowej w kursach brało udział jedynie osiemdziesięciu studentów ${ }^{24}$. Spośród wybitnych studentów Filii Paryskiej można wymienić choćby Jana Cybisa, Józefa Czapskiego, Józefa Jaremę, Artura Nacht-Samborskiego, Hannę Rudzką-Cybis, Piotra Potworowskiego czy Zygmunta Waliszewskiego ${ }^{25}$. Trzeba też wspomnieć o charyzmie Józefa Pankiewicza, profesora krakowskiej Akademii od 1906 r., kierownika Filii Paryskiej od 1925 r., który będąc wybitnym malarzem, był też wybitnym pedagogiem, kontakt $\mathrm{z}$ nim chciało mieć wielu młodych adeptów sztuki, zwłaszcza kolorystów ${ }^{26}$.

Moda na wyjazdy do Paryża trwała przez całe dwudziestolecie międzywojenne, choć zaczęła się już znacznie wcześniej, jeszcze w XIX w. Już w 1910 r. krytyk Wacław Husarski zauważył: „Tak więc przyjeżdża młodzież polska do Paryża, wykształcona po krakowsku, tj. umiejąca bezmyślnie malować strzechy omszałe, kwitnące sady, nadwiślańskie topole i całą tę, dziś nieco spowszedniałą poezję wsi polskiej, albo wykształcona po warszawsku, to jest wiedząca o literackim, nastroju, o literackiej perwersji, ale nic zgoła niewiedząca o sztuce. Cała ta młodzież bez żadnego przygotowania rzuca się do muzeów, pociągają ją przeważnie prymitywy, zwłaszcza włoskie [...]. Mogłoby to umiłowanie prymitywów bardzo dobre przynieść skutki, mogłoby nawet dobrze przetrawione być podstawą do polskiej szkoły malarskiej, do której wzdychamy [...]. Tym lichym, $\mathrm{w}$ danym razie jest nasze nieszczęście, bezkrytyczne lecenie za modą, nowinką"27. Wyjazdy Polaków do Francji i podejmowanie przez nich tematyki „niepolskiej” ganił w 1913 r. przy okazji Salonu Jesiennego Wacław Gąsiorowski ${ }^{28}$.

Z drugiej strony, jak podsumowała Anna Wierzbicka: „Podczas gdy przed 1918 rokiem główną motywacją wyjazdu twórców z kraju była chęć zdobycia wykształcenia artystycznego, tak później, w latach dwudziestych i trzydziestych,

23 Anna Mayer, Filia Paryska Akademii Sztuk Pięknych w Krakowie, Kraków 2003, s. 173.

24 Ibidem, s. 13, 183.

25 Ibidem, s. 10; Góra Sylwia, Nauczanie malarstwa i rysunku w Akademii Sztuk Pięknych w Krakowie w latach 1818-2018 [w:] 200 lat Akademii Sztuk Pięknych w Krakowie 1818-2018, t. 1, red. Adam Wsiołkowski, Jacek Dembosz, Paulina Tendera, Kraków 2019, s. 133.

26 Ibidem, s. 131-135.

27 Mayer, Filia Paryska..., s. 55.

28 Anna Wierzbicka, Nasi czy obcy? Dyskusja wokół dwóch wystaw kolonii artystów polskich we Francji w dwudziestoleciu międzywojennym [w:] Migracje. Materiały LXV Ogólnopolskiej Sesji Naukowej Stowarzyszenia Historyków Sztuki. Warszawa, 24-25 listopada 2016 r., red. Anna Sylwia Czyż, Katarzyna Chrudzimska-Uhera, Warszawa 2017, s. 258. 

ze świetnym gronem profesorskim. Opuszczali więc ojczyznę z innych powodów - aby wziąć udział w międzynarodowym życiu artystycznym, zaistnieć za granicą, poszerzyć wiedzę. Niektórzy po paru latach spędzonych za granicą, w czasie których odbyli tzw. „grand tour” i odwiedzili nie tylko Paryż, ale także inne centra artystyczne w Europie - Berlin czy Wiedeń, wracali do Polski”29. Według teoretyków „styl francuski” wiązał się z dobrą techniką i warsztatem, zatem wyjazdy miały na celu ich usprawnienie ${ }^{30}$. Wyjazdy do Paryża cieszyły się w drugiej połowie lat trzydziestych XX w. nieustającym powodzeniem - mimo kryzysu ekonomicznego, niezmiennego problemu z utrzymaniem się przez artystów ${ }^{31}$, coraz większej popularności nazizmu i faszyzmu oraz faktu, że według opinii wielu Paryż tracił w tym czasie status czołowego centrum artystycznego ${ }^{32}$.

„Pojechaliśmy do Paryża - pisała po latach Żuławska - gdzie od kilku lat profesor Pankiewicz prowadził pracownię malarską jako filię Akademii Krakowskiej i przyjmował młodych malarzy z Polski, jak mawiał, «na dokształcenie». Byliśmy właśnie po absolutorium w warszawskiej Akademii Sztuk Pięknych"33. Sam Pankiewicz, który co prawda od 1 września 1935 r. przeszedł na emeryturę, ale prowadził Oddział Paryski ASP jako pracę zleconą ${ }^{34}$, wspominał o Hannie, wtedy jeszcze Jasińskiej, pisząc 8 marca 1936 r. do Sekretariatu Akademii Sztuk Pięknych w Krakowie odnośnie spraw studentów Oddziału Paryskiego: „w załączniku przesyłam listę kwalifikacyjną. Rodowód i 3 fotografie p. Jasińskiej [...]"35. Zaś 28 maja 1938 r. pisał do rektoratu krakowskiej ASP w sprawie wysyłki prac studentów Oddziału Paryskiego: „Prace studentów Oddziału Paryskiego: Jasińskiej, Żuławskiego, Lilpopówny, w liczbie 55 wysłane zostały do Krakowa przed tygodniem [...]"36.

29 Eadem, Świadectwa obecności. Polskie życie artystyczne we Francji 1900-1939, cz. 3, Lata 1930-1939, Warszawa 2016, s. 17; eadem, Nasi czy obcy?..., s. 264.

30 Ibidem, s. 275.

31 Krejčí Marek, W poszukiwaniu wzorców nowoczesności. Paryskie doświadczenia polskich i czeskich artystów [w:] Sztuka lat 1905-1923. Malarstwo, rzeźba, grafika, krytyka artystyczna. Materiały z konferencji naukowej Toruń, 21-23 września 2005 r., red. Małgorzata Geron, Jerzy Malinowski, Toruń 2006, s. 121-128.

32 Jak napisała Anna Wierzbicka: „Tendencję tę zauważył już w 1930 roku Waldemar George, zastanawiając się, czy Paryż pozostanie centrum artystycznym świata, narzekając na brak znaczących wystaw, utrudnioną dostępność do zbiorów i apelując o program artystyczny uwypuklający sztukę francuską. Rolę wiodącego centrum przejmie Nowy Jork, który utrzyma tę pozycję także po 1945 roku”, zob. Wierzbicka, Świadectwa obecności..., s. 31.

33 Żuławska, Jacek Żuławski..., s. 25, 27. Dyplom warszawskiej ASP artystka uzyskała już po drugiej wojnie światowej, w $1947 \mathrm{r}$.

34 Pankiewicz pracował w ten sposób w latach 1935-1936 i 1936-1937. Jego następcą był Wacław Zawadowski, zob. Mayer, Filia Paryska..., s. 171.

35 Ibidem, s. 168.

36 Ibidem. 
Stypendium o równowartości 50 zł nie starczało na zbyt wiele, chociaż można przypuszczać, że Hanna miała pomoc finansową od swojej rodziny. Z narzeczonym żyli skromnie ${ }^{37}$, ale prowadzili wesołe życie bohemy. Zgodnie $\mathrm{z}$ wymogami programowymi Filii Paryskiej kopiowali dzieła starych mistrzów ${ }^{38}$. Zwiedzali zarówno Luwr, w którym zachwycali się dziełami Veronese’a i Tycjana, jak i galerie sztuki, gdzie poznawali bliskie Hannie - ze względu na sposób operowania kolorem - malarstwo Pierre'a Bonnarda i Jean-Édouard'a Villarda oraz nowocześniejsze prądy: kubizm i abstrakcjonizm, na obrazach Pabla Picassa, Georgesa Braque’a i Juana Grisa. Jak jednak twierdziła Hanna, „obydwa te nurty [kubizm i abstrakcjonizm - przyp. autorki] interesowały nas, ale byliśmy za młodzi i niedoświadczeni, a ponadto zbyt zafascynowani sztuką Francji, aby opowiedzieć się po stronie koloru czy też ekspresji. Właściwie w tym czasie nie mogliśmy malować, tylko patrzyliśmy i chłonęliśmy"39.

Artystka na dobre zafascynowała się malarstwem przyjaciela swego wykładowcy - Bonnarda ${ }^{40}$. Za sprawą Pankiewicza, który prowadził na Rue Bonaparte 24 dom otwarty i traktował studentów po przyjacielsku, poznała Olgę Boznańską (zapewne słowo poznała należy interpretować bardzo dosłownie, raczej nie była to znajomość głęboka, po prostu najpewniej młoda malarka została jej jedynie przedstawiona; Boznańska stanowiła w XX w. rodzaj „atrakcji towarzyskiej", którą każdy szanujący się artysta polski przybywający do Francji chciał zobaczyć, poznać, a przynajmniej chwalić się w kraju, że ją poznał) ${ }^{41}$. Żuławska wspominała: „Pamiętam z tego okresu uroczą wizytę u Olgi Boznańskiej, do której zaprowadził nas Profesor. W dziwnej, dużej, nieco mrocznej pracowni na podium siedziała szczupła pani w kitlu i malowała coś w prawym rogu na zaczętym obrazie, nie zwracając uwagi na gości, którzy siedzieli lub kręcili się poniżej podium, rozmawiając ściszonym głosem. Niektórzy mieli w ręku filiżankę $\mathrm{z}$ cienkiej porcelany $\mathrm{z}$ herbatą, nam też taką przyniosła jakaś starsza pani. Herbata była letnia i miałam wrażenie, że filiżanki nieczęsto się myło"42. Józefa Wnukowa pisała natomiast, że Żuławscy w czasie pobytu na dworze w Łańcuchowie wiosną 1945 r. „wspominali z czułością wizyty u Olgi Boznańskiej w ciemnej pracowni, w której piło się tradycyjną herbatę, podczas gdy gospodyni cały czas malowała, nie zwracając uwagi na gości”43.

\footnotetext{
37 Według słów Hanny, dostawała ona ledwie pół stypendium, zaś Jacek nie otrzymywał go wcale, pobyt finansował mu (podobną kwotą około 50 zł) ojciec, znany polityk, zob. ibidem, s. 34 .

38 Jadwiga Dmochowska, W kręgu Pankiewicza, Kraków 1963, s. 192.

$39 \quad$ Ibidem, s. 32, 33.

40 Józef Czapski, Józef Pankiewicz, Życie i dzieło, Lublin 1992, s. 84-85.

${ }^{41}$ Angelika Kuźniak, Boznańska non finito, Kraków 2019, tu s. 275-278; Agnieszka Bagińska, U Olgi Boznańskiej. Oblicza pracowni artystki, Toruń 2013, s. 39-40, 45-46; Joanna Sosnowska, Poza kanonem. Sztuka polskich artystek 1880-1939, Warszawa 2003, s.106-107; Andrzej Pieńkos, Dom sztuki. Siedziby artystów w nowoczesnej kulturze europejskiej, Warszawa 2005, s. 78.

42 Żuławska, Jacek Żuławski..., s. 34.

43 Józefa Wnukowa, Śladami Jacka Żuławskiego [w:] Jacek Żuławski..., s. 60.
} 
Aleksandra Juszczyk

W 1936 r. artyści wrócili na chwilę do Warszawy, by wziąć udział w dwóch wystawach Instytutu Propagandy Sztuki - w listopadzie w Warszawie (od 6 do 17) i w Łodzi (otwartej 12 grudnia). Na obu tych wystawach Hanna zaprezentowała te same prace: 21 gwaszy przedstawiających widoki Paryża, martwe natury, w tym martwe natury kwiatowe, a także cztery projekty polichromii ściennych ${ }^{44}$. Dzieła te nie zachowały się do dziś, a informację o nich (tytuły) można znaleźć jedynie w katalogu prac wystawy IPS- $\mathrm{u}^{45}$. Mieczysław Wallis tak oceniał prace zaprezentowane przez młodą malarkę w czasie warszawskiej ekspozycji: „Jasińska projektuje malowidła ścienne przedstawiające »Muzykę«, »Śpiew«, »Teatr«, »Taniec«, utrzymane w miłej różowo-błękitnej gamie barwnej. Ramy z tynku tych szkiców mają mówić nam, że są one pomyślane w związku ze ścianą i murem. Na razie, nie mogąc urzeczywistnić swych projektów na wielkich płaszczyznach ściennych, artystka maluje gwaszem ładne widoki Paryża i Bretanii" ${ }^{46}$.

Po przyjeździe do Paryża plastycy wynajęli pracownię na zamieszkałej przez artystów Impasse Du Ruet, na co pozwoliło uzyskane przez Jacka francuskie stypendium ${ }^{47}$. Bogate kontakty (m.in. z Józefem Natansonem, Arturem Nacht-Samborskim, Eugeniuszem Eibischem, Wacławem Zawadowskim i - przede wszystkim - ze znanym francuskim krytykiem sztuki André Salmonem) dały im w końcu możliwość wystawienia swych obrazów. Prace pokazywano publiczności od 21 maja do 6 czerwca $1938 \mathrm{r}^{48} \mathrm{w}$ uznanej, powstałej w $1862 \mathrm{r}$., paryskiej galerii sztuki „Bernheim-Jeune”, mieszczącej się przy Avenue Matignon $^{49}$. Galeria ta w dwudziestoleciu międzywojennym była jedną $\mathrm{z}$ najbardziej prestiżowych $\mathrm{w}$ Paryżu, promowała zarówno sztukę awangardową, impresjonistów i postimpresjonistów, jak i twórców École de Paris. Wystawiała dzieła Georges'a Seurata Pierre’a Bonnarda, Paula Cèzanne’a, Édouarda Vuillarda, Henri Matisse'a, Vincenta van Gogha ${ }^{50}$, Amadeo Modiglianiego, Marca Chagalla, Georges’a Braque’a, Umberto Boccioniego, Pablo Picassa czy też Mojżesza Kislinga i Józefa Pankiewicza oraz wielu innych znakomitych artystów. Istotny był fakt, że „Bernheim-Jeune” była galerią z tradycjami, francuską i przez Francuzów prowadzoną, gdyż wielu artystów z Polski wystawiało swe prace w galeriach

44 Sprawozdanie z działalności Instytutu Propagandy Sztuki, „Nike” 1937, R. 1, s. 234.

45 Wystawa prac Hanny Jasińskiej i Jacka Żuławskiego IPS [katalog wystawy], Warszawa 1936, s. 5.

46 Mieczysław Wallis, Hanna Jasińska, Jacek Żuławski (I.P.S.), „Wiadomości Literackie” 1936, nr 51, s. 6.

${ }^{47}$ Informacja o uzyskaniu francuskiego stypendium za Kalendarium [w:] Jacek Żuławski..., s. 172. O Jacku Żuławskim jako o „stypendyście” wspominał Pankiewicz w liście z dn. 2 grudnia 1937 r. do Rektoratu Akademii w Krakowie, zob. Mayer, Filia Paryska..., s. 188.

48 „Les Amicis de la Pologne” 1938, nr 6/7, s. 184.

49 F.L.K [Felicja Lilpop Krance], Wystawy paryskie. E. Vuillard. Polscy artyści, „Gazeta Polska” 1938 r, nr 168, s. 5.

50 W galerii „Bernheima Młodszego” - jak ją nazywano, miała miejsce pierwsza wystawa Vincenta van Gogha. 
w dużej mierze „polonijnych” ${ }^{1}$ jak choćby w Galerie Zak, prowadzonej przez Jadwigę Zakową (Jadwigę Kohn-Zak) ${ }^{52}$.

Można uznać, że droga ta była bardzo typowa, by nie rzec sztampowa. Przytoczę w tym miejscu fragment książki Anny Wierzbickiej, opowiadający, co prawda, o artystach École de Paris, ale pasujący do opisu paryskich poczynań sześciu polskich malarzy: „Jeśli prześledzimy ich paryskie kariery, zobaczymy, że przebiegły podobnie. Po przybyciu do Paryża młody, nieznany cudzoziemiec szukał przede wszystkim swoich ziomków lub znajomych. Ci zaś przedstawiali nowicjusza swojemu marszandowi lub handlarzowi sztuki, który z kolei wprowadzał go na rynek. Artysta zwykle zawierał z marszandem kontrakt, a ten szukał klientów chętnych do nabycia jego prac. Zyskiwał ich dzięki wystawom. Prace mało znanego twórcy początkowo eksponowano razem z pracami jego kolegów lub uznanych Francuzów. Dzięki tym ekspozycjom znajdował nie tylko pierwszych klientów, ale też zwracał uwagę krytyków. Następnym celem było «zdobycie» prawego brzegu, gdzie znajdowały się prestiżowe galerie - Bernheim, Bing czy Rosenberg. Gdy artyście udało się tu wystawić, krąg jego klientów zazwyczaj wzrastał" ${ }^{33}$. Można domniemywać, że polscy artyści byli jednak realistami i zdawali sobie sprawę z otaczającego ich kryzysu oraz z faktu, że na większy sukces w sprzedaży swoich prac nie mogą raczej liczyć - pojawili się po prostu w Paryżu o jakąś dekadę za późno. Sama wystawa była już dla nich dużym osiągnięciem.

W „Exposition de six peintres polonaise”, którą „zorganizowali artyści i sami byli dla siebie «Komitetem», sami kwalifikowali swoje prace i dlatego selekcja była tak surowa. [...] Przyjechali do Paryża nie po to, aby wystawiać, ale po to, aby się w Paryżu uczyć, a rozwiesili swe prace nie po to, aby «imponować», ale po to, by zweryfikować swoje płótna, aby je zweryfikować z tymi założeniami, które kształtowały ich twórczość, bo [...] świadomie «ex definitione» nawiązują do malarstwa francuskiego [...] jeśli się dziś nawiązuje do malarstwa francuskiego, to przecież nie dlatego, że jest to «sztuka francuska», ale po prostu: jedynie malarstwo francuskie leży dziś na tej wielkiej linii malarstwa, która rozwija się od renesansu" - jak opisywał znajomy grupy, Bolesław Miciński ${ }^{54}$. Istotnie, Żuławska wspominała: „Mieliśmy wielką tremę, cały czas przewieszaliśmy obrazy, aż wystawa wydała nam się dobra" ${ }^{55}$.

Autorem wstępu do katalogu wystawy był słynny i prominentny krytyk francuski polskiego pochodzenia, zajmujący się sztuką francuską i niemiecką - Waldemar George (a właściwie Jerzy Waldemar Jarociński), czołowy publicysta dwudziestolecia międzywojennego we Francji, korespondent „Wiadomości Literackich", autor Profits et pertes de l'art. Contemporain, od lat trzydziestych XX w. przeciwnik sztuki awangardowej i jednocześnie zwolennik, idei „humanizacji”

\footnotetext{
Zob. Anna Wierzbicka, Ecole de Paris. Pojęcie, środowisko, twórczość, Warszawa 2004, s. 20. Do 1932 r. (do śmierci marszanda) istniała też „Galerie Zborowski” Leopolda Zborowskiego. Wierzbicka, Ecole de Paris..., s. 73.

Bolesław Miciński, Polscy malarze w Paryżu, „Prosto z mostu” 1938, nr 29, s. 4.

Żuławska, Jacek Żuławski..., s. 35.
}

Wczesny okres twórczości Hanny Żuławskiej... 
Aleksandra sztuki, w której człowiek miał być „wzorcem myśli, bytem, mikrokosmosem”, Juszczyk a nie tylko problemem i tematem form ${ }^{56}$. Pozyskanie George’a było z pewnością nobilitacją dla sześciorga polskich artystów, bo choć wspierał on młodych malarzy przyjeżdżających do Francji w celu pogłębienia studiów lub z zamiarem osiedlenia się tam na stałe (zwłaszcza tych z Polski; także z École de Paris), a przynajmniej miał do nich stosunek pozytywny (o ile dostrzegł w ich twórczości polskie cechy narodowe, przez które - mało precyzyjnie - rozumiano nostalgię, subtelność, liryzm, melancholię i romantyzm, i uznał ją za „sztukę przystosowaną do człowieka") ${ }^{57}$, pozyskanie jego pomocy w opracowaniu katalogu ekspozycji było sprawą prestiżową i niezbyt często spotykaną. Oczywiście sztuka prezentowana przez Polaków nie była w najmniejszym stopniu awangardowa, co zapewne miało wpływ na decyzję krytyka. Fragment wychwalającego polskich artystów tekstu George’a i notkę mówiącą o wystawie zamieściło fran-

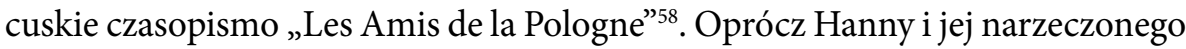
swój dorobek zaprezentowali także Krystyna Łada, Juliusz Studnicki, Zbigniew Zdzisław Ruszkowski i Jan Wacław Zawadowski - jedyny spośród całego towarzystwa, który mieszkał we Francji od około dwudziestu lat. Znajoma Żuławskich, Halina Kenarowa, wspominała: „Wszyscy byliśmy podnieceni tym wydarzeniem, czerwcowy poranek był piękny i dwie białe salki w galerii Bernheima dźwięczały dyskretnie niewielkimi obrazami sześciu polskich malarzy. Pamiętam wytworną sylwetkę Hani w czarnym jedwabnym płaszczyku na kwiecistej sukni i czarny słomkowy kapelusz z wielkim rondem kryjącym w cieniu jej wydatny nos, a pogłębiający błękit oczu i puszystą złocistość włosów"59.

Według korespondenta „Wiadomości Literackich”, malarza Henryka Gotliba: „Wystawa sześciu polskich malarzy, która odbyła się w salach wystawowych «Bernheim Jeune», jednej z najpoważniejszych galerii Paryża, jest godna uwagi $\mathrm{z}$ wielu powodów. Przede wszystkim dlatego, że $\mathrm{z}$ wyjątkiem Wacława Zawadowskiego, który od dwudziestu nieomal lat stale mieszka i pracuje w Paryżu, wszyscy inni przyjechali do Francji stosunkowo niedawno i przywieźli ze sobą z kraju przekonania i atmosferę charakterystyczne dla najmłodszego pokolenia naszych malarzy. Patrząc na obrazy Anny Jasińskiej, Zdzisława Ruszkowskiego, Juliusza Studnickiego, Krystyny Łady-Studnickiej i Jacka Żuławskiego, trudno oprzeć się wrażeniu, że mimo dużych różnic, jest coś łączącego wszystkich tych artystów. Wydaje się, jakby malarze ci, stając przed białym płótnem z pędzlem w ręku,

56 Andrzej K. Olszewski, Krytyka sztuki nowoczesnej we Francji [w:] Sztuka dwudziestolecia międzywojennego. Materiały Sesji Historyków Sztuki. Warszawa, październik 1989, red. Anna Marczak, Warszawa 1989, s. 51-55.

57 Waldemar George uznał np. za niereprezentatywną dla polskiej sztuki współczesnej (zapewne z powodu udziału w niej artystów pochodzenia żydowskiego) wystawę w Galerie des Beaux Arts (8-23 listopada 1935 r.), w której wzięli udział członkowie Grupy Paryskiej Plastyków Polskich, m.in. Władysław Jahl, Oktawian Jastrzębski, Zygmunt Menkes, a także Olga Boznańska i Józef Pankiewicz, zob. Wierzbicka, Nasi czy obcy?..., s. 268, 274, 275-276.

58 „Les Amis de la Pologne” 1938, nr 6/7, s. 184.

59 Halina Kenarowa, Dzieje przyjaźni [w:] Jacek Żuławski..., s. 48. 
zapełniali je stopniowo, krok za krokiem, kolorowymi plamami, wynalezionymi na palecie dla pokazania gry barwnych plam, składających się na trochę owoców na stole, na grupę drzew na przedmieściu, na figurę ludzką stojącą lub siedzącą"60.

Jak zauważyła po przyjacielsku w „Gazecie Polskiej” Felicja Lilpop Krance, mieszkająca wówczas w Paryżu studentka Pankiewicza: „Wystawa jest dobra i interesująca. Istnieje tu pewien moment wspólny, a mianowicie wyrównany poziom, owa kultura, którą dla uproszczenia sprawy nazywa się w kraju francuską, mimo że właśnie prasa francuska podkreśla odrębność narodową, polskie spojrzenie na świat. Francuzem z kultury i rzemiosła nazywa krytyk Waldemar George profesora Zawadowskiego, który objął w tym roku kierownictwo oddziału paryskiego krakowskiej Akademii Sztuk Pięknych, dotąd prowadzonej przez prof. Pankiewicza. Przydomek francuski zyskały sobie jeszcze na Salonie Warszawskim I.P.S. prace Studnickiego i Łady, mimo że zetknięcie się tych malarzy z Francją nastąpiło dopiero teraz, a wystawione płótna powstały wyłącznie w kraju. Jasińska, Żuławski i Ruszkowski cały zgromadzony dorobek zawdzięczają paru latom pracy w Paryżu, co świadczy chlubnie, że z pożytkiem dla siebie umieli ten czas wyzyskać" ${ }^{\prime 1}$.

W opinii samej Żuławskiej ekspozycja, „oceniając ją z perspektywy lat [...], nie była żadną bombą nowoczesności, była po prostu kawałkiem dobrego malarstwa, które spotkało się z przychylną krytyką. Twierdzono nawet, że na gruncie paryskim miała cechy świeżości i egzotyzmu"62.

Hanna zaprezentowała na niej, jak się wydaje, dosyć typowe dla koloryzmu, by nie rzec konwencjonalne, obrazy z często podejmowanymi przez malarzy tematami - z widokami francuskiej stolicy, np. Rue Rivoli (il. 4), Bulwar Montparnasse, i krajobrazami (Sekwana). Warto nadmienić, że pokazanie przez artystkę na wystawie pejzaży miało także zapewne podłoże merkantylne: paryskie widoki cieszyły się po prostu powodzeniem wśród francuskich nabywców sztuki i wielu malarzy prezentowało je z rozmysłem, licząc na zarobek w niełatwym dla handlu sztuką czasie. Według recenzentki „Gazety Polskiej”, „Anna [...] Jasińska pokazała się tym razem głównie jako pejzażystka. Z wyjątkiem dwu martwych natur, $z$ których żółte żonkile na stole przykrytym białą serwetą i z żółtymi jabłkami na talerzu, utrzymane są w ładnej dźwięcznej harmonii - resztę stanowią fragmenty ulic i placów paryskich, malowane bardzo bezpośrednio i z umiarem kolorystycznym, w gamie opartej na szafirowych fioletach, ziemi zielonej i brązach" ${ }^{63}$.

Lilpop Krance bardziej przypadły do gustu pejzaże Krystyny Łady, gdyż określiła je jako „bardziej komponowane, bardziej wyszukane i ważone” [niż pejzaże Jasińskiej - przyp. autorki], na których już „natura malowana jest nie wprost”. Miciński widział płótna Żuławskiej w ten sposób: „Jasińska jest pod wpływem

60 Henryk Gotlib, Wystawa sześciu Polaków w Paryżu, „Wiadomości Literackie” 1938, nr 30, s. 4.

61 F.L.K. [Felicja Lilpop Krance], Wystawy paryskie..., s. 5.

62 Żuławska, Jacek Żuławski..., s. 35.

63 F.L.K [Felicja Lilpop Krance], Wystawy paryskie..., s. 5. 


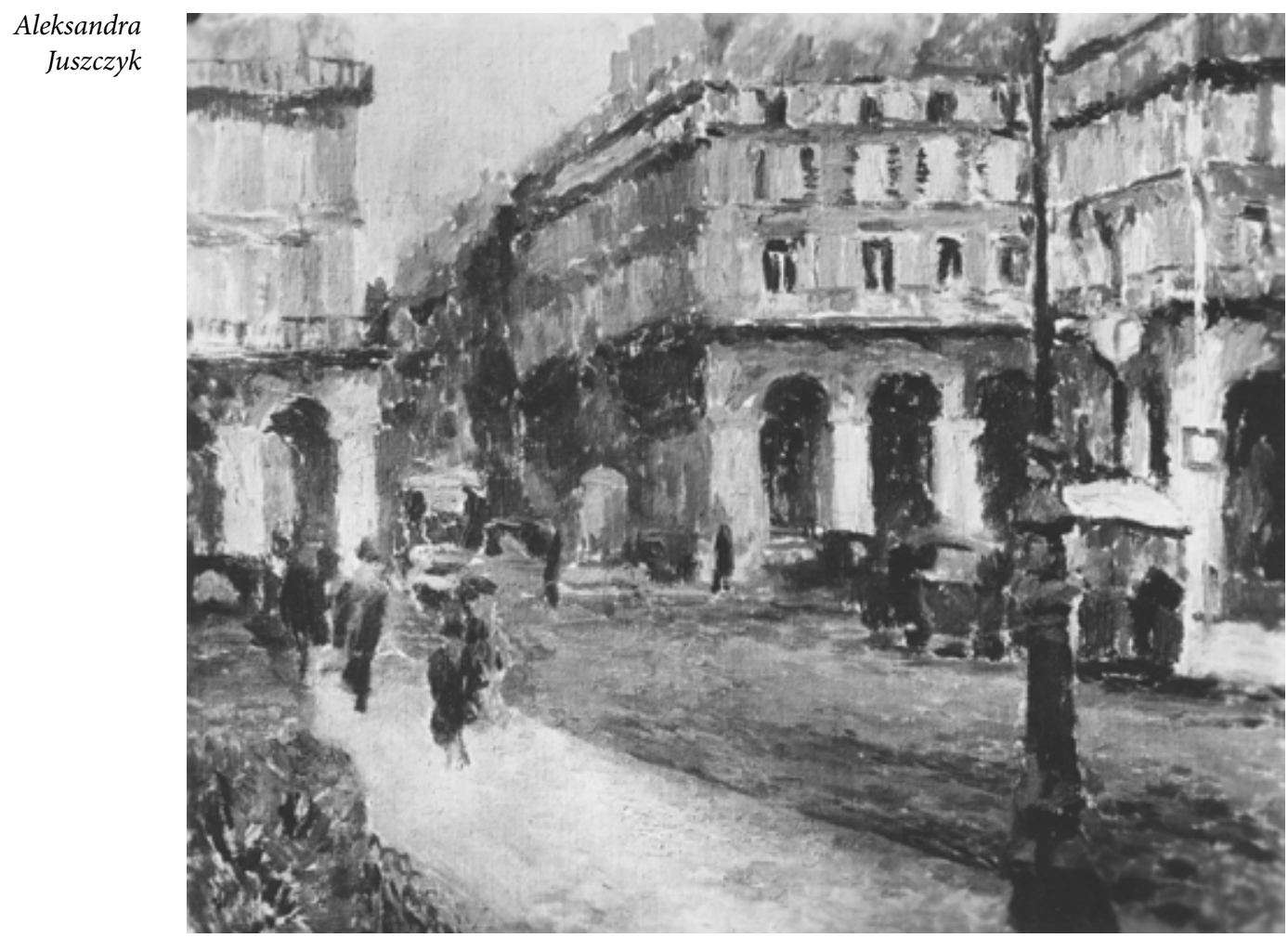

Il. 4. Hanna Żuławska, Rue Rivoli, 1938, olej, Narodowe Archiwum Cyfrowe

impresjonistycznego widzenia świata: wartość jej obrazów jest raczej związana $\mathrm{z}$ dobrym widzeniem niż z świadomym działaniem koloru na kolor. Plamy i formy różnicują się już w precyzyjnym spojrzeniu transparentnym tylko na płótno" ${ }^{4}$. Recenzent „Wiadomości Literackich” Gotlib zauważył natomiast: „Kiedy patrzę na pejzaże Jasińskiej lub Studnickiego, na niektóre martwe natury Ruszkowskiego lub Żuławskiego, zdaje mi się, że jedyną rzeczą, którą wolno by mi było zauważyć, jest to, że ta lub tamta plama może być namalowana innym kolorem, bardziej szarym czy bardziej barwnym, o nieco innej tonacji. Niektóre z wystawionych obrazów nie budzą pod tym względem żadnych wątpliwości, są to obrazy najlepsze, doprowadzone do zupełnej równowagi. [...] Jasińska i Studnicki [w przeciwieństwie do Żuławskiego i Ruszkowskiego, u których „można zauważyć elementy budowania widzenia malarskiego" - przyp. autorki] poddają się niemal biernie kolorowym sugestiom wycinków z natury, nie zdobywając się na chwyt aktywny albo może świadomie wyłączając go ze swej estetyki”"65.

65 Gotlib, Wystawa sześciu Polaków w Paryżu..., s. 4. 
Wystawa paryska doczekała się oddźwięku w Polsce, co w drugiej połowie lat trzydziestych XX w. nie było już takie oczywiste, ponieważ recenzje i dłuższe omówienia (nie licząc krótkich wzmianek informacyjnych) wystaw Polaków w Paryżu raczej nie pojawiały się już w polskiej prasie. Jedną z przyczyn tej sytuacji (prócz dezintegracji polskiej kolonii artystycznej) była dyskusja na temat polskiej sztuki narodowej i wzrastająca, zwłaszcza od czasu wystawy „Art. Polonais moderne w Éditions Bonaparte" (19 października - 20 listopada 1929 r.), niechęć do czerpania wśród artystów wzorców ze sztuki niepolskiej i wszystkiego co „obce"66. Niechęć taką żywił Mieczysław Treter, zwolennik stylu narodowego, ludowości, redaktor „Sztuk Pięknych” - pisma bardzo niechętnego polskiej kolonii artystycznej w Paryżu (zwłaszcza artystom pochodzenia żydowskiego), dyrektor Towarzystwa Szerzenia Sztuki Polskiej Wśród Obcych (TOSSPO), a także krytycy i publicyści związani ze środowiskiem prawicowym, jak choćby Zygmunt Wasilewski i Stanisław Pieńkowski, współpracujący z „Myślą Narodową”, ponadto Jan Kleczyński, Władysław Skoczylas i Józef Czajkowski ${ }^{67}$. W prasie francuskiej zaś, wliczając wspomniane czasopismo promujące kontakty polsko-francuskie, o ekspozycji sześciu polskich artystów jedynie krótko wzmiankowano ${ }^{68}$. Można zatem wysnuć przypuszczenie, że wystawa znalazła oddźwięk jedynie na gruncie polskim, pozostając niemal niezauważona w Paryżu - i nic dziwnego, bowiem w stolicy Francji działo się wtedy relatywnie wiele $e^{69} \mathrm{i}$ niedługo otwarta wystawa artystów z Polski była zapewne wydarzeniem istotnym dla nich samych, kręgu ich znajomych, odbiorców w Polsce, nie zaś dla krytyki i wybrednego, wyrobionego widza paryskiego.

Czerwiec 1938 r. był istotny dla Hanny z jeszcze jednego powodu: 28 czerwca w merostwie XIX Dzielnicy Paryża wzięła ślub cywilny z Żuławskim (il. 5). W podróż poślubną wyjechali (na trzy tygodnie) do Włoch, gdzie zwiedzili Wenecję i Florencję, lecz do Paryża już nie powrócili ze względów finansowych. Jako obcokrajowcy bez prawa pobytu, bez jakiegokolwiek stypendium, mieli ogromne problemy z utrzymaniem się z malarstwa w trudnych dla handlu sztuką czasach. Po krachu na Wall Street sytuacja gospodarcza Francji pogarszała się z roku na rok, zaś bezrobocie w 1935 r. wzrosło do dwóch milionów. Sytuacja polityczna była równie trudna: popularność zyskiwały partie skrajnie prawicowe o faszystowskim zabarwieniu, realne było zagrożenie nazizmem. Tym samym po latach prosperity, w których także kolonia artystów z Polski odnosiła największe sukcesy, po tzw. „złotym” okresie (1922-1929), sytuacja artystów się pogorszyła. Zmianie uległo zwłaszcza położenie twórców zagranicznych, którzy do końca lat dwudziestych XX w. dominowali na francuskim rynku sztuki i byli lansowani przez marszandów także najczęściej pochodzących zza granicy. Imigranci mieli - jak głoszono w prasie - zabierać miejsca pracy rodowitym twórcom francuskim

66 Wierzbicka, Świadectwa obecności..., s. 18.

67 Eadem, Nasi czy obcy?..., s. 252-257, 263, 266.

68 Art. Les Galeries d'art., „La Semaine a Paris” 1938, nr 834, s. 36; Art. Les Galeries d'art, „La Semaine a Paris” 1938, nr 836, s. 40, za: Wierzbicka, Polskie życie artystyczne..., s. 468.

69 Pomimo kryzysu wystawienniczego i w handlu dziełami sztuki. 


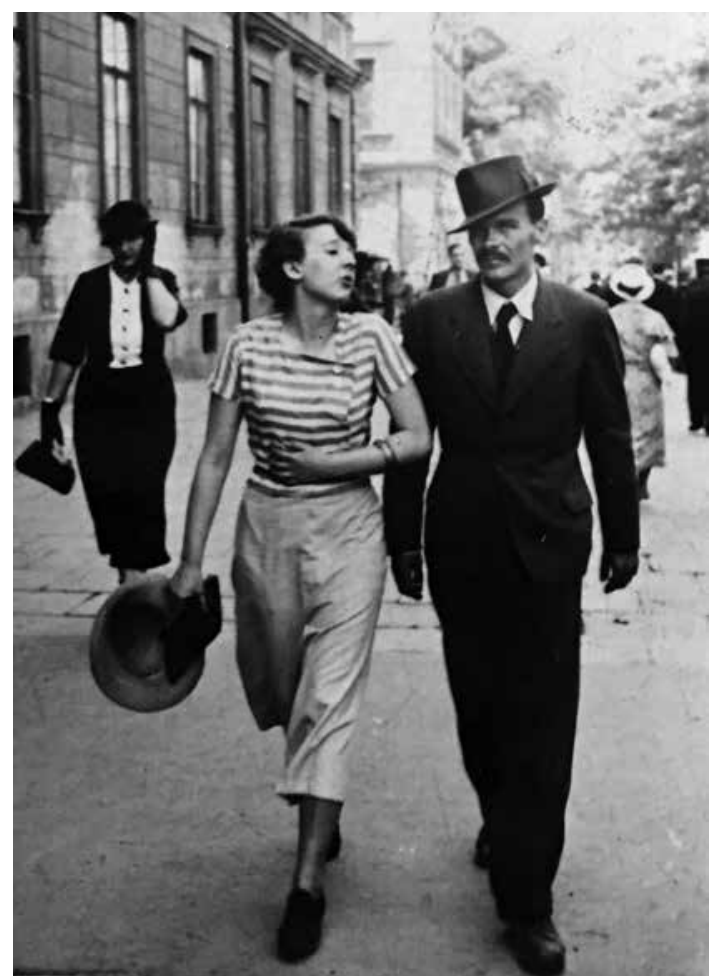

Il. 5. Hanna i Jacek Żuławscy po ślubie w Paryżu, 1938, fot. ze zbiorów prywatnych poprzez dominację na rynku sztuki, byli posądzani o korupcję i spekulacje; narastał antysemityzm ${ }^{70}$. Zamykano galerie, marszandzi bankrutowali, degradacji uległa dzielnica Montparnasse, zamieszkiwana głównie przez cudzoziemców $^{71}$. Nic dziwnego, że ubożejąca publiczność paryska raczej nie była zainteresowana kupowaniem obrazów pary polskich malarzy, a wydaje się, że i ojciec Jacka Żuławskiego, Zygmunt, prominentny polityk PPS, miał już dość łożenia na paryskie życie trzydziestoletniego syna artysty i jego wybranki artystki. Co prawda Jacek Żuławski próbował utrzymać narzeczoną (a później żonę) w Paryżu, dorabiając, jak pisała Hanna, ilustracjami do "pisma myśliwskiego" i robiąc "napisy francuskie do kina, jeżeli filmy były w innym języku”, ale „wszędzie go wyzyskiwali - wiadomo, cudzoziemiec, meteque bez prawa do pracy"72.

Wydaje się, że Hanna nie miała najmniejszych złudzeń co do tego, że sama - przede wszystkim jako kobieta - nie zrobi artystycznej kariery w Paryżu, nie zarobi na własne utrzymanie. Kobiety - plastyczki, nawet te najzdolniejsze, po prostu nie były w okresie międzywojennym we Francji traktowane poważnie i (z małymi wyjątkami) nie miały szans na kariery porównywalne do męskich czy też do dziewiętnastowiecznej kariery Rosy Bonheur lub Polek: Anny Bilińskiej-Bohdanowicz i Olgi Boznańskiej $^{73}$, (później) Melanii Muttermilch (Meli Muter). Nawet dobrze zapowiadające się malarki pełniły po zamążpójściu rolę żony przy uznanym mężu (jak choćby Maria Wanda Pankiewicz, Hanna Rudzka-Cybis czy Jadwiga Kohn-Zak, która odniosła sukces jako właścicielka popularnej galerii dopiero po śmierci męża w 1926 r. ${ }^{74}$. Zresztą mimo niepełnej i niedostatecznej znajomości jej dzieł z tego

$70 \quad$ Wierzbicka, Nasi czy obcy?..., s. 251, 267.

71 Eadem, Świadectwa obecności..., s. 7-8.

72 Żuławska, Jacek Żuławski..., s. 35.

73 Zob. m.in. Maria Poprzęcka, Anna Bilińska-Bohdanowicz [w:] Artystki polskie, red. Agata Jakubowska, Warszawa 2011, s. 173-177; eadem, Olga Boznańska [w:] Artystki polskie..., s. 185-189.

74 Sylwia Zientek, Polki na Montparnassie, Warszawa 2021, s. 323, 324, 393; Anna Markowska, Hanna Rudzka-Cybis [w:] Artystki polskie..., s. 223. 
okresu można przyjąć, że i sama Żuławska nie zaprezentowała w tym okresie nic wybitnego, nowatorskiego, wychodzącego poza sztampowe ramy.

Hanna wspominała, że pomijając realistyczny osąd możliwości życia i zarabiania w Paryżu, po prostu chcieli wrócić z mężem do Polski, zapewne po to, by żyć w warunkach bardziej komfortowych i stabilnych, mieć większe perspektywy, tworzyć w swoim kraju. Dziełem, które wywarło na artystce ogromne wrażenie jeszcze przed wyjazdem z Francji, była Guernica Picassa.

Wiosną 1938 r. artyści zamieszkali w Gdyni. W Ministerstwie Oświaty zaproponowano nowożeńcom posady nauczycieli plastyki w Liceum Handlowym, z czego skwapliwie skorzystali już jesienią 1938 r. „Pojechaliśmy tam chętnie - nęciły nas możliwości żeglarskie" 75 - pisała Hanna o Gdyni. Latem 1936 r. powstał tu nowoczesny Basen Żeglarski. Żuławscy, zapaleni żeglarze, brali udział w rejsach i regatach, byli działaczami Polskiego Yacht Clubu, uczestniczyli w opływaniu nowych jednostek. Jacek poznał zresztą Gdynię już wcześniej, jako nastolatek jeździł razem z bratem Markiem do Gdyni, Sopotu i Gdańska na obozy żeglarskie, więc namówienie go do zamieszkania nad morzem nie było zapewne trudne ${ }^{76}$. Gdynia, nowe polskie miasto nad morzem, była po prostu modna, zaś jej życie kulturalne i artystyczne w latach trzydziestych nie było z pewnością nudne. Być może Żuławscy wiązali z Gdynią swe plany artystyczne na przyszłość: miasto to było idealnym miejscem rozwoju zawodowego dla artystów parających się malarstwem monumentalnym ze względu na budowę nowych budynków użyteczności publicznej wymagających dekoracji. Prace propagandowe w okresie II Rzeczypospolitej łączyły się z zainteresowaniami monumentalnymi technikami malarstwa ściennego, nadającymi się znakomicie do dekoracji tego typu reprezentacyjnych budynków. Jak zauważył w 1937 r. Józef Bieniasz: „Gdynia jest [...] miastem budowanym przez całą Polskę, skupia na sobie uwagę całego narodu jako port narodowy i stanowi instrument polityki ogólnopaństwowej" ${ }^{\prime 7}$. Gdynia była też miastem znanym małżeństwu Żuławskich już wcześniej, przyjeżdżali do niej na wakacje pływać w regatach jako członkowie Akademickiego Związku Morskiego, a potem Yacht Klubu Polskiego. Do miasta przyjechali też $\mathrm{w}$ tym czasie znajomi Żuławskich z warszawskich czasów studenckich, a następnie z okresu paryskiego - Juliusz Studnicki i Krystyna Łada (potem Łada-Studnicka).

Co interesujące, wydaje się, że pobyt nad morzem nie spowodował, że Żuławska zaczęła malować morskie pejzaże, a raczej morze nie stało się dla niej malarskim natchnieniem ${ }^{78}$.

75 Ibidem, s. 36.

76 Encyklopedia Gdyni, Gdynia 2006, s. 50; Zmorzyński, Marek i Jacek..., s. 27.

77 Józef Bieniasz, Zagadnienia kulturalne Gdyni i Wybrzeża, „Wiadomości Literackie” 1937, nr 27, s. 19.

78 Pomijając nieliczne prace oraz zlecenia państwowe, jak choćby zlecenie na mozaikową dekorację holu dworca w Gdyni już po drugiej wojnie światowej, zob. m.in. Stanisław Czekalski, Unista nad morzem. O pejzażach morskich Władysława Strzemińskiego [w]: Podróże artystyczne. 
Aleksandra Juszczyk

Żuławska brała jednocześnie udział w warszawskich wystawach, w listopadzie 1938 r. uczestniczyła w X (ostatnim) Salonie IPS-u, odebrała nawet jedno $\mathrm{z}$,zaszczytnych wyróżnień” $\mathrm{w}$ dziedzinie malarstwa za dwa obrazy namalowane jeszcze w Paryżu: Bulwar Montparnasse oraz Sekwana ${ }^{79}$. „Zaprzyjaźniliśmy się od razu z paczką architektów. Byli to Tadeusz Kossak, Bogdan Damięcki, Stefan Reichman i Bronisław Malisz - to właśnie oni projektowali gmachy i budynki przedwojennej Gdyni”"80 - wspominała Żuławska. Wydaje się, że równie prędko nawiązali istotne kontakty koleżeńskie z czołowymi przedstawicielami gdyńskiego życia artystycznego, malarzami Zygmuntem Cywińskimi i Marianem Bohuszem-Szyszko, wywodzącymi się z tego samego środowiska artystycznego i mającymi podobne doświadczenia oraz zapatrywania na sztukę. Nie można też wykluczyć, że wszyscy ci artyści poznali się w Warszawie w czasie studiów, zaś w Gdyni po prostu odnowili dawną znajomość, w następstwie czego już w $1938 \mathrm{r}$. Żuławscy przystąpili do gdyńskiego oddziału Związku Zawodowego Polskich Artystów Plastyków (ZZPAP). Nowy oddział Związku Zawodowego Artystów Plastyków w Gdyni, założony 17 stycznia 1937 r., liczył szesnastu członków (malarzy, grafików, architektów, dekoratorów i rzeźbiarzy) i był, o czym się wciąż bardzo rzadko wspomina, pierwszym i jedynym w północnej Polsce. Wcześniej powstało pięć oddziałów w najbardziej rozwiniętych artystycznie miastach: w Krakowie, Warszawie, Lwowie, Łodzi i Poznaniu. Główną oś ZZPAP stanowili artyści „niezrzeszeni”, związani z koloryzmem (także kapiści), oraz plastycy $\mathrm{z}$ kręgów awangardy. Związek za cel stawiał sobie w pierwszym rzędzie obronę interesów zawodowych polskich artystów plastyków. Jednakże poważnym założeniem ideowym ZZPAP było zdecydowane występowanie przeciwko wszelkim przejawom nacjonalizmu, „państwowotwórczości” w sztuce polskiej. Zrzeszenie negowało - popierany przez rząd sanacyjny - program sztuki oficjalnej i tradycjonalistyczny mecenat niektórych instytucji powołanych do opieki nad sztuką, hamujący swobodę działania artystycznego.

Opinie na temat działalności gdyńskiego ZZAP były dość zróżnicowane, jedni widzieli w nim podmiot dość żywo działający na artystycznym firmamencie Gdyni ${ }^{81}$, inni - jak choćby Jan Zamojski czy Artur Maria Swinarski - „amatorów przedstawiających przeraźliwie niski poziom ${ }^{82}$ " i ,stowarzyszenie kanapowe o charakterze bardziej towarzyskim niż artystycznym", ograniczające się

Artysta w podróży, red. Ryszard Kasperowicz, Jacek Jaźwierski, Marcin Pastwa, Lublin 2010, s. 237-254; Liliana Giełdon, Gdynia i morze w malarstwie Michaliny Krzyżanowskiej [w:] Polska nad Bałtykiem, red. Dariusz Konstantynów, Małgorzata Omilanowska, Gdańsk 2012, s. 111-119; Monika Jankiewicz-Brzostowska, Polskie morze w twórczości Włodzimierza Nałęcza \{w:] Polska nad Bałtykiem, red. Dariusz Konstantynów, Małgorzata Omilanowska, Gdańsk 2012, s. 93-109.

79 Na wystawie zgromadzono 269 prac malarskich, graficznych i rzeźbiarskich ponad 180 artystów, zob. „Tygodnik Ilustrowany” 1938, nr 48, s. 921-923. Por. też X Salon IPS. Malarstwo, grafika, rzeźba. Katalog wystawy, Warszawa 1938, s. 16.

80 Żuławska, Jacek Żuławski..., s. 36.

81 Henryk Chudziński, Monografia Wielkiego Pomorza i Gdyni, Toruń-Lwów1939, s. 97-98.

82 Jan Zamoyski, Łukaszowcy - malarze i malarstwo Bractwa św. Łukasza, Warszawa 1989, s. 94. 
do „dancingów i pokazów mody” ${ }^{33}$. Jak odnotował Swinarski, zdegustowany środowiskiem artystycznym Gdyni, lecz doceniający prace Żuławskiej: „Raz, dwa razy do roku mamy w Gdyni «Salon». Wiszą tam obrazy, które z powodzeniem mogłyby wisieć w IPS-ie czy u Bernheima. Wystawia Jacek Żuławski i jego żona Hanna, Roman Białokoz i jego żona Teodora, Marjan Szyszko-Bohusz i jego żona Zofia, bo artyści czują się trochę nieswojo na tutejszym gruncie i wolą chodzić parami. Odbywa się zwiedzanie wystawy, fachowa dyskusja i krytyka. A więc: Roman i Teodora Biełokozowie mówią o obrazach Jacka i Hanny Żuławskich, a Hanna i Jacek Żuławski mówią o tkaninach Teodory i Romana Biełokozów, natomiast Marjan Szyszko-Bohusz mówi o Marjanie Szyszko-Bohuszu. I raczej przychylnie. To wszystko" 84 . Małżeństwa artystyczne były zresztą w dwudziestoleciu międzywojennym bardzo popularne (zwłaszcza wśród twórców awangardy albo kapistów), na co zwróciła uwagę Joanna Sosnowska ${ }^{85}$. Twórcy awangardowi często byli związani ze środowiskami lewicującymi, co wiązało się zazwyczaj z brakiem forsowania męskiego dyktatu; ojciec Jacka był politykiem PPS - młodzi także mieli przekonania socjalistyczne a co za tym idzie, mąż nie umniejszał roli Hanny jako twórczyni lub czynił to w niewielkim stopniu.

Mimo dość marginalnego, w porównaniu $\mathrm{z}$ innymi ośrodkami, znaczenia gdyńskiej filii ZZAP do wybuchu drugiej wojny światowej zorganizowano w ramach jego działalności około szesnastu wystaw - zarówno w ramach Salonów Wiosennych i Zimowych, jak i ekspozycji indywidualnych ${ }^{86}$. Żuławska przed wybuchem drugiej wojny światowej zdążyła jeszcze wziąć udział w wystawie Salonu w kwietniu 1939 r. Sama artystka wspominała, że gdy rozeszła się wieść o światowcach, którzy przyjechali do Gdyni z Paryża (a wcześniej studiowali w warszawskiej ASP), by prezentować najświeższe trendy w sztuce (oczywiście niewiele było w tym prawdy, bo i malarstwo Żuławskiej nie miało nic wspólnego $\mathrm{z}$ awangardą $\mathrm{i}$ w późnych latach trzydziestych XX w. nawet w Gdyni musiało zostać uznane za zachowawcze), zainteresowanie jej działalnością (i męża) wzrosło i szybko zaczęło procentować. Małżeństwo otrzymało propozycję wykonania nowych projektów dekoracji monumentalnych ${ }^{87}$ : malowideł

3 Artur Maria Swinarski, Gdynianin a Muzy, „Słowo [Słowo Wilno]” 1939, nr 131, s. 5.

84 Ibidem, s. 5.

85 Sosnowska, Artystki w dwudziestoleciu..., s. 69-70, 77.

86 Andrzej Bukowski, Życie kulturalne i literackie Gdyni [w]: Gdynia, sylwetki ludzi, oświata, kultura i nauka, Gdańsk 1979, s. 173; Jerzy Strumieński, Dwadzieścia lat środowiska plastycznego na Wybrzeżu [w]: „Gdańskie Zeszyty Humanistyczne. Prace Pomorzoznawcze” 1967, R. 10, nr 15, s. 53.

${ }_{87}$ Projekty te się nie zachowały. W końcu lat trzydziestych nie było w Gdyni równie świetnie wykształconych artystów, którzy mogliby z sukcesem artystycznym robić tego typu zlecenia. Co prawda, w 1936 r. Stanisław Teisseyre, mający doświadczenie w tworzeniu malowideł ściennych w lwowskich i podlwowskich świątyniach, stworzył polichromię Domu Marynarza Szwedzkiego, zaś kierownik Państwowej Szkoły Sztuk Plastycznych Wacław Szczeblewski dekorował choćby „Nowy Dwór Kaszubski” czy Szpital Miejski w Gdyni. Natomiast do pracy przy czołowym dziele malarstwa architektonicznego - wystroju Gimnazjum Polskiego im. Józefa Piłsudskiego, nie na terenie Polski, a w Wolnym Mieście Gdańsku, zatrudniono uznanych artystów związanych 

malowideł do kaplicy Szpitala Sióstr Miłosierdzia przy pl. Kaszubskim. Dzieła te nie zostały zrealizowane z powodu wybuchu wojny, nic też nie wiadomo na temat projektów, które zapewne przepadły w pożodze wojennej. Można się jednak domyślać, że mimo iż w Gdyni Żuławscy uchodzili za „nowoczesnych”, wystrój malarski utrzymany był w duchu „państwowotwórczym”, ideologicznym, nacjonalistycznym w treści i w formie, z przedstawieniami alegorycznymi, zachowawczym i niezbyt awangardowym ${ }^{88}$.

Na początku września 1939 r. małżonkowie, zostawiając cały swój dotychczasowy, powstały w Polsce i we Francji, dorobek artystyczny, wyjechali do Warszawy. „[... ] Jedyny rok samodzielnej pracy i radości na morzu minął błyskawicznie” - pisała Żuławska. „Jak wiele zapowiadał możliwości! Wyjeżdżając z Gdyni w 1939 r., zostawiliśmy wszystko, w tym cały nasz dorobek artystyczny, także z Paryża, aby odejść od sztuki na całe cztery ciemne lata wojny" ${ }^{\prime 9}$. Wojnę spędziła w Warszawie, na Saskiej Kępie.

W listopadzie 1944 r. Żuławska zamieszkała w domu pracy twórczej w Łańcuchowie nad Wieprzem niedaleko Lublina (Jacek dołączył do niej zaraz po wyzwoleniu Krakowa $)^{90}$. W tym samym 1944 r. Hanna została przyjęta w poczet członków Związku Polskich Artystów Plastyków okręgu lubelskiego i odnowiła znajomość ze Stanisławem Teysseyre i Juliuszem Studnickim oraz Krystyną Łada-Studnicką, nawiązała też bliższą relację z Józefą i Marianem Wnukami. Wydaje się, że to wtedy też zainicjowano pierwsze rozmowy na temat powstania wyższej szkoły plastycznej na Wybrzeżu - co otworzyło nowy rozdział w artystycznym życiu Żuławskiej. Według informacji zawartych w katalogach wystaw z lat osiemdziesiątych XX w. artystka miała w 1944 r. w Lublinie indywidualną wystawę w „Kawiarni Plastyków”. Można przypuszczać, że jedną z prezentowanych prac był Wymarsz wojsk (il. 6). W 1845 r. brała udział w wystawie zbiorowej ${ }^{91}$, jednak nic więcej na temat tych ekspozycji nie wiadomo.

Zarówno edukacja, jak i kierunek „podróży artystycznych” (Paryż, Włochy) Żuławskiej były dosyć typowe dla wielu artystów rozpoczynających swą drogę twórczą w okresie dwudziestolecia międzywojennego, podobnie jak fascynacje artystyczne (koloryzm, Veronese, Tycjan, Pierre Bonnard i Jean-Édouard Villard, a także kubizm i abstrakcjonizm), choć niewątpliwe, na co wskazuje późniejszy

z Bractwem Świętego Łukasza, na co dzień niemieszkających nad morzem: Jana Zamoyskiego, Bolesława Cybisa, Mariana Jurgielewicza i Stefana Płużańskiego.

88 Zob. Iwona Luba, Duch romantyzmu i modernizacja, Warszawa 2012, s. 167-188; Agnieszka Chmielewska, Wyobrażenia polskości, Warszawa 2019, s. 11-71 i dalsze.

89 Żuławska, Jacek Żuławski..., s. 38.

$90 \quad$ Wnukowa, Jacek Żuławski..., s. 53.

${ }_{91}$ Hanna Żuławska. 100 figurek ceramika, [katalog wystawy], Warszawa 1981, s. 2; Hanna Żuławska. Dzień dzisiejszy [katalog wystawy], Bydgoszcz 1984, s. 2; Hanna Żuławska. Dzień dzisiejszy, Sopot 1984, s. 3. 


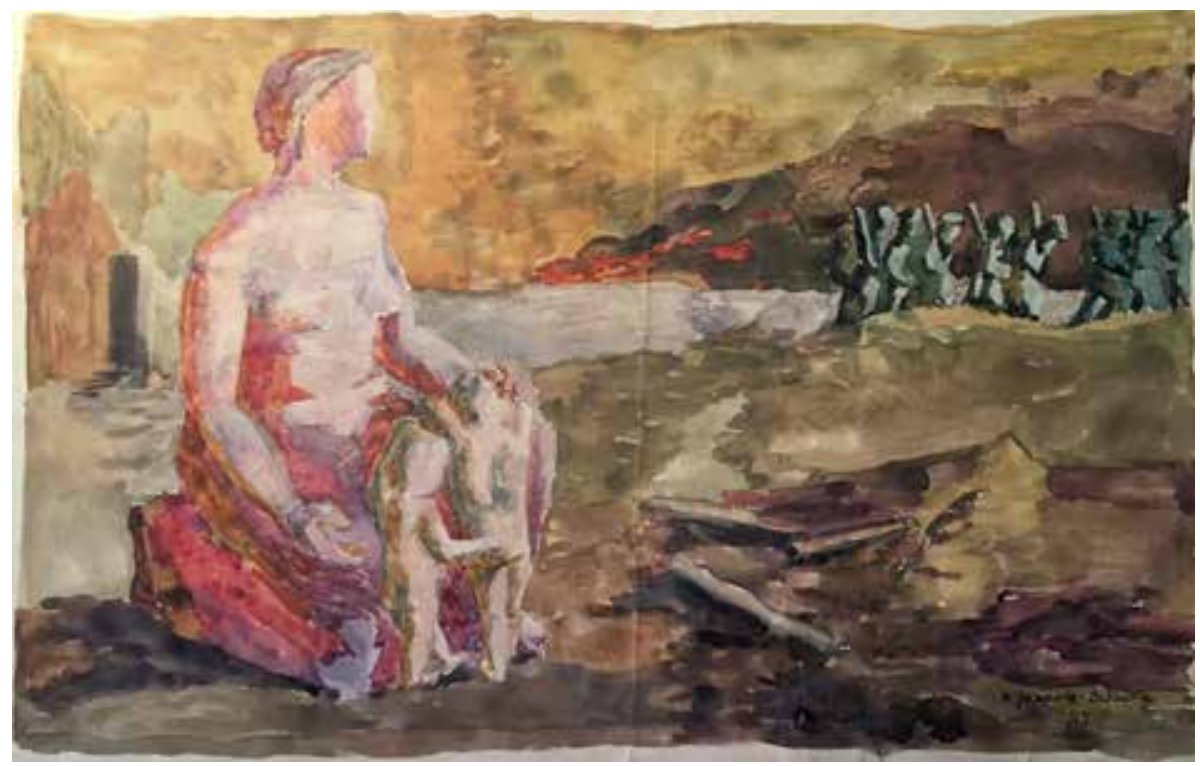

Wczesny okres twórczości

Hanny

Żuławskiej...

Il. 6. Hanna Żuławska, Wymarsz wojsk, 1944, akwarela, zbiory prywatne, fot. Aleksandra Juszczyk

okres jej twórczości, inspiracje Picassem były trwałe, mimo że dotyczyły bardziej jego twórczości jako ceramika. Z pewnością bardzo ważną postacią dla artystki, jej pierwszym i, wydaje się, że najważniejszym, mentorem był Felicjan SzczęsnyKowarski, ale także Leonard Pękalski - dzięki nim zainteresowała się malarstwem monumentalnym, sgraffitem, mozaiką architektoniczną, które zapewniały jej największe uznanie po wojnie. Malarstwo sztalugowe Żuławskiej z tego czasu było najpewniej dosyć sztampowe, inspirowane twórczością kapistów, bez śladów wpływu awangardy malarskiej, jednak - sądząc z tego, co pisano w recenzjach - przejawiało stabilny, dobry poziom, co podkreślała większość recenzentów. Z pewnością nie uważano Żuławskiej za indywidualność twórczą, raczej była jedną z niezłych, ale szeregowych malarek. Artystka brała aktywny udział w wystawach (IPS), doskonaliła warsztat, pomagając w realizacji projektów swojego profesora, „nabierała szlifów” - wtedy też zapewne zaczął się kształtować jej indywidualny styl. W czasie studiów na warszawskiej Akademii i później - w Gdyni, poznała artystów, z którymi po drugiej wojnie światowej stworzyła pierwszą polską plastyczną uczelnię wyższą na Wybrzeżu. Z pewnością w swej pracy na tej uczelni pedagogicznej wykorzystywała doświadczenia wynikające z kontaktów z najwybitniejszymi polskimi artystami - dydaktykami: Kowarskim czy Pankiewiczem. Nie wydaje się natomiast, by młodzieńcza fascynacja koloryzmem wywarła trwały wpływ na jej malarstwo. $Z$ pewnością wpływy koloryzmu można znaleźć na obrazach z przełomu lat pięćdziesiątych i sześćdziesiątych XX w. oraz w martwych naturach z kwiatami z lat osiemdziesiątych. Jednak z czasem artystka przestała tworzyć pejzaże i martwe natury, 
a portretów nie malowała wcale, jej paleta stawała się monochromatyczna, ciemna, a tematykę obrazów stanowiły sceny rodzajowe z elementami groteski, czarnego humoru.

Żuławska wniosła znaczący wkład w rozwój życia artystycznego w przedwojennej Gdyni pomimo krótkiego, nieco ponadrocznego pobytu w tym mieście: stała się aktywną członkinią gdyńskiego oddziału Związku Zawodowego Polskich Artystów Plastyków, wystawiała w jego ramach prace na lokalnych „Salonach”. Z pewnością była już wtedy jedną z bardziej wyrazistych i uznanych artystek na Wybrzeżu (oczywiście trzeba mieć na uwadze, że środowisko artystyczne w Gdyni było jednak dość prowincjonalne), jedną z niewielu dobrze wykształconych, obeznanych poprzez podróże ze sztuką francuską i włoską, zarówno tradycyjną, jak i awangardową, utrzymującą kontakt $z$ najwybitniejszymi polskimi artystami, wystawiającą w prestiżowej paryskiej galerii. Przed drugą wojną światową otrzymała też w Gdyni pierwsze samodzielne (nie jako osoba pomagająca w pracy, podległa) ważne zlecenia na realizacje monumentalne. Otrzymała te zlecenia jako kobieta - w sztuce oficjalnej II Rzeczypospolitej kobiety często odgrywały znaczącą rolę i dostawały zamówienia państwowe $^{92}$. Fakt ten musiał mieć wpływ na to, że po wojnie, w socjalistycznej rzeczywistości, uznano twórczynię za „specjalistkę" od wielkoformatowych przedstawień architektonicznych i proponowano jej duże zlecenia państwowe, choć oczywiście, jak zauważyła Joanna Sosnowska, pozycja kobiet i mężczyzn po drugiej wojnie światowej uległa zmianie, nastąpiło zrównanie charakterystyczne dla sytuacji ekstremalnych ${ }^{93}$.

\section{Bibliografia}

Bagińska Agnieszka, U Olgi Boznańskiej. Oblicza pracowni artystki, Toruń 2015.

Chmielewska Agnieszka, Wyobrażenia polskości, Warszawa 2019.

Chudziński Henryk, Monografia Wielkiego Pomorza, Toruń-Lwów1939.

Czapski Józef, Józef Pankiewicz. Życie i dzieło. Wypowiedzi o sztuce, Lublin 1992.

Czekalski Stanisław, Unista nad morzem. O pejzażach morskich Władysława Strzemińskiego [w]: Podróże artystyczne. Artysta w podróży, red. Ryszard Kasperowicz, Jacek Jaźwierski, Marcin Pastwa, Lublin 2010, s. 237-254.

Dmochowska Jadwiga, W kręgu Pankiewicza, Kraków 1963.

Encyklopedia Gdyni, red. Małgorzata Sokołowska, Izabella Greczanik-Filipp, Wiesława Kwiatkowska, Gdynia 2006.

Friedrich Jacek, Walka obrazów, Przedstawienia wobec idei w Wolnym Mieście Gdańsku, Gdańsk 2018.

Gdynia, sylwetki ludzi, oświata, kultura i nauka, red. Andrzej Bukowski, Gdańsk 1979.

92 Przykładem może być tu Zofia Stryjeńska, zob. Luba, Duch romantyzmu..., s. 50-52.

93 Sosnowska, Artystki w dwudziestoleciu..., s. 80. 
Giełdon Liliana, Gdynia i morze w malarstwie Michaliny Krzyżanowskiej [w:] Polska nad Bałtykiem. Konstruowanie identyfikacji kulturowej państwa nad morzem 1918-1938, red. Dariusz Konstantynów, Małgorzata Omilanowska, Gdańsk 2012, s. 111-119.

Góra Sylwia, Nauczanie malarstwa i rysunku w Akademii Sztuk Pięknych $w$ Krakowie w latach 1818-2018 [w:] 200 lat Akademii Sztuk Pięknych w Krakowie 1818-2018, t. 1, red. Adam Wsiołkowski, Jacek Dembosz, Paulina Tendera, Kraków 2019, s. 133. Jacek Żuławski, red. Hanna Żuławska, Gdańsk 1987.

Jankiewicz-Brzostowska Monika, Polskie morze w twórczości Włodzimierza Nałęcza [w:] Polska nad Bałtykiem. Konstruowanie identyfikacji kulturowej państwa nad morzem 1918-1938, red. Dariusz Konstantynów, Małgorzata Omilanowska, Gdańsk 2012, s. 93-109.

Kuźniak Angelika, Boznańska non finito, Kraków 2019.

Krejčí Marek, W poszukiwaniu wzorców nowoczesności. Paryskie doświadczenia polskich i czeskich artystów [w:] Sztuka lat 1905-1923. Malarstwo, rzeźba, grafika, krytyka artystyczna. Materiały z konferencji naukowej Toruń, 21-23 września 2005 r., red. Małgorzata Geron, Jerzy Malinowski, Toruń 2006, s. 121-128.

Luba Iwona, Duch romantyzmu i modernizacja, Warszawa 2012.

Markowska Anna, Hanna Rudzka-Cybis [w:] Artystki polskie, red. Agata Jakubowska, Warszawa 2011, s. 221-226.

Materiały dziejów Instytutu Propagandy Sztuki (1930-1939), red. Joanna Sosnowska, Warszawa 1990.

Mayer Anna, Filia Paryska Akademii Sztuk Pięknych w Krakowie w świetle materiatów archiwalnych, Kraków 2003.

Olszewski K. Andrzej, Krytyka sztuki nowoczesnej we Francji w dwudziestoleciu międzywojennym [w:] Sztuka dwudziestolecia międzywojennego, red. Anna Marczak, Warszawa 1982, s. 47-57.

Omilanowska Małgorzata, Propaganda wizualna „Polski morskiej” [w:] Polska nad Battykiem. Konstruowanie identyfikacji kulturowej państwa nad morzem 1918-1938, red. Dariusz Konstantynów, Małgorzata Omilanowska, Gdańsk 2012, s. 8-16.

Państwowa Wyższa Szkoła Sztuk Plastycznych w Gdańsku, red. Józefa Wnukowa, Toruń 1978.

Pawłowska Aneta, Pro Arte. Monografia grupy warszawskich artystów 1922-1932, Warszawa 2006.

Pieńkos Andrzej, Dom sztuki. Siedziby artystów w nowoczesnej kulturze europejskiej, Warszawa 2005.

Polski słownik biograficzny, t. 11 (1), z. 48, red. Emanuel Rostworowski, Warszawa 1964.

Polskie życie artystyczne $w$ latach 1915-1939, t. 2, red. Aleksander Wojciechowski, Wrocław-Warszawa-Kraków-Gdańsk 1974.

Poprzęcka Maria, Anna Bilińska-Bohdanowicz [w:] Artystki polskie, red. Agata Jakubowska, Warszawa 2011, s. 173-177.

Poprzęcka Maria, Olga Boznańska [w:] Artystki polskie, red. Agata Jakubowska, Warszawa 2011, s. 185-189.

Słownik artystów plastyków: artyści plastycy Okręgu Warszawskiego ZPAP 1945-1970, red. Maria Serafińska, Warszawa 1972.

Słownik artystów polskich i obcych $w$ Polsce działających, Malarze, rzeźbiarze, graficy, t. 3, red. Jolanta Maurin-Białostocka, Janusz Derwojed, Wrocław 1979. 
Aleksandra Juszczyk

Sosnowska Joanna, Artystki w dwudziestoleciu [w:] Artystki polskie, red. Agata Jakubowska, Warszawa 2011, s. 65-81.

Sosnowska Joanna, Poza kanonem, Sztuka polskich artystek 1880-1939, Warszawa 2003. Tomczyk-Watrak Zofia, Wybory i przemilczenia: od szkoły sopockiej do nowej szkoły gdańskiej, Gdańsk 2001.

Wierzbicka Anna, Ecole de Paris. Pojęcie, środowisko, twórczość, Warszawa 2004.

Wierzbicka Anna, Nasi czy obcy? Dyskusja wokół dwóch wystaw kolonii artystów polskich we Francji w dwudziestoleciu międzywojennym [w:] Migracje. Materiały LXV Ogólnopolskiej Sesji Naukowej Stowarzyszenia Historyków Sztuki Warszawa, 24-25 listopada 2016 r., red. Anna Sylwia Czyż, Katarzyna Chrudzimska Uhera, Warszawa 2017, s. 249-279.

Wierzbicka Anna, We Francji i w Polsce 1900-1939, Warszawa 2009.

Wierzbicka Anna, Świadectwa obecności. Polskie życie artystyczne we Francji 1900-1939, cz. 3, Lata 1930-1939, Warszawa 2016.

Witz Ignacy, Plastycy Wybrzeża, Gdańsk 1969.

Zagrobelny Andrzej, Twórczość Juliusza Studnickiego w okresie dwudziestolecia międzywojennego, „Porta Aurea” 2012, t. 11, s. 269-285.

Zientek Sylwia, Polki na Montparnassie, Warszawa 2021.

Zmorzyński, Wojciech, Marek i Jacek Żuławscy: malarstwo, rysunek [katalog wystawy], Muzeum Narodowe, Gdańsk 2002.

\section{The Early Period of Hanna Żuławska's work. Warsaw-Paris-Gdynia}

Hanna Żuławska (1908-1988) was one of the most prominent artists associated with the Tri-City, and dealing with many fields of art: easel and polychrome painting, architectural mosaic, sgraffito, ceramics and small architecture. Her husband was a painter known on the coast: Jacek Żuławski. She is known primarily for her mature work in the 1950s and 60s; it was then that she showed true individuality. From post-war times, Żuławska was also teacher and professor at the State Higher School of Fine Arts in Gdańsk and the manager of the Kadyny Ceramics Works. Little, if anything, is known of Hanna Żuławska's work in the interwar period.

In 1930-1934, Żuławska studied at the Warsaw School of Fine Arts, among others in the studios of Professors Felicjan Szczęsny Kowarski, Leonard Pękalski and Tadeusz Pruszkowski. It seems that Kowarski's work in the fields of painting and monumental mosaics had a great influence on Żuławskass later artistic activity. In the 1930s, Żuławska took part in exhibitions at IPS (Art Propaganda Institute).

At that time, the artist experienced a period of fascination with the works of the members of the Paris Committee and Pierre Bonnard and Paul Cèzanne, which resulted in the pair of the artists, Hanna and Jacek, leaving for Paris on a scholarship in 1935. In Paris, the artist studied in the painting studio of Józef Pankiewicz, painted still lifes, city views and quite standard landscapes; she also visited museums and led a lively social life. In May 1938, the works of Hanna and five other Polish painters were presented at the prestigious Bernheim Jeune gallery in Paris. The exhibition was well received by critics in Poland. 
Hanna and her husband returned to Poland and settled in Gdynia in the autumn of 1938, where Żuławska established contacts with the artistic community of the city. In 1938, the artists joined the Gdynia branch of the Trade Union of Polish Artists and Designers, and actively participated in its exhibitions until the outbreak of World War II. In recognition of their contribution to the development of art in Gdynia, the Żuławskis also received state orders for a monumental painting decoration of the barracks' common room at Redłowo, for the creation of paintings for the Chapel of the Hospital of the Sisters of Mercy at Kaszubski Square, and for the polychrome entitled 'Apotheosis of Gdynia' in the building of the Government Commissariat (designs not preserved).

During the Nazi occupation, the Żuławskis were in Warsaw; in November 1944, the artist came to Łańcut near Lublin, where she stayed at an artistic house. In the autumn of 1945, Hanna and Jacek Żuławski together with other residents of the manor house, e.g.: Juliusz Studnicki, Krystyna Łada-Studnicka, Janusz Strzałecki, Józefa and Marian Wnuk, established the State Institute of Fine Arts in Sopot, transformed into the State Higher School of Fine Arts in Gdańsk. 